\title{
Recent changes in Arctic Ocean circulation revealed by iodine-129 observations and modeling
}

\author{
Michael Karcher, ${ }^{1,2}$ John N. Smith, ${ }^{3}$ Frank Kauker, ${ }^{1,2}$ Rüdiger Gerdes, ${ }^{2}$ \\ and William M. Smethie Jr. ${ }^{4}$ \\ Received 29 August 2011; revised 14 June 2012; accepted 14 June 2012; published 3 August 2012.
}

[1] Anthropogenic radionuclides released into European coastal waters from nuclear fuel reprocessing plants at Sellafield (UK) and La Hague (France) flow northward through the Nordic Seas and label Atlantic Water (AW) entering the Arctic Ocean. Transport of the soluble radionuclide ${ }^{129}$ I through the Arctic Ocean has been simulated using a numerical model for the period from 1970 to 2010 . The simulated tracer distributions closely conform to ${ }^{129}$ I measurements made across the Arctic Ocean during the mid-1990s and 2000s and clearly illustrate the dramatic changes in oceanic circulation which occurred during this time. The largest changes in surface circulation were associated with the transition from a negative to a positive phase of the Arctic Oscillation in the early 1990s and the subsequent return to a weak positive phase in the late 1990s and early 2000s.

Model and experimental results indicate that a new circulation regime evolved after 2004 when a period of intense, anti-cyclonic surface stress led to a strengthening of the Beaufort Gyre. We submit that this resulted in a suppression of the cyclonic boundary current of mid-depth Atlantic Water (AW) below the Beaufort Gyre, with upper AW in the Canada Basin showing signs of a reversal from cyclonic to anti-cyclonic flow. These results are consistent with the development of a new AW circulation scheme involving a separation between flow at intermediate depths in the Eurasian and Canada Basins which could eventually result in modification of the Arctic intermediate water which feeds the overflows.

Citation: Karcher, M., J. N. Smith, F. Kauker, R. Gerdes, and W. M. Smethie Jr. (2012), Recent changes in Arctic Ocean circulation revealed by iodine-129 observations and modeling, J. Geophys. Res., 117, C08007, doi:10.1029/2011JC007513.

\section{Introduction}

[2] For the past several decades a suite of radionuclides that includes ${ }^{129} \mathrm{I}$ and ${ }^{137} \mathrm{Cs}$, has been released from European nuclear fuel reprocessing plants in Sellafield (UK) and La Hague (France) [Kershaw and Baxter, 1995] and transported northward through the Nordic Seas into the Arctic Ocean (Figure 1). This transport constitutes the dominant source for these tracers in northern latitudes. These radionuclides serve as oceanographic tracers for water of Atlantic origin in the Arctic Ocean and have provided substantial insight into water circulation time scales and the fate of contaminants from the industrialized zones of Europe [Smith et al., 1998,

\footnotetext{
${ }^{1}$ O.A.Sys - Ocean Atmosphere Systems GmbH, Hamburg, Germany.

${ }^{2}$ Alfred Wegener Institute for Polar and Marine Research, Bremerhaven, Germany.

${ }^{3}$ Bedford Institute of Oceanography, Fisheries and Oceans Canada, Dartmouth, Nova Scotia, Canada.

${ }^{4}$ Lamont Doherty Earth Observatory, Palisades, N.Y., USA.

Corresponding author: M. Karcher, Alfred Wegener Institute for Polar and Marine Research, Columbusstrasse, PO Box 120161, Bremerhaven, Bremen DE-27515, Germany. (michael@oasys-research.de)

(C)2012. American Geophysical Union. All Rights Reserved. 0148-0227/12/2011JC007513
}

1999, 2011; Gascard et al., 2004]. ${ }^{129} \mathrm{I}$ is particularly well suited for circulation studies in the central Arctic, because ${ }^{129}$ I sample collection is simple and the ${ }^{129} \mathrm{I}$ data set for research cruises using icebreakers, nuclear submarines and aircraft during the 1990s and 2000s is relatively large. In addition, the ${ }^{129}$ I release functions for the two point sources are well documented and exhibit sufficiently sharp increases in the early 1990s (Figure 1, inset) that downstream time series ${ }^{129}$ I measurements can provide a clear expression of upstream flow parameters [Smith et al., 2011]. However, there remain significant spatial and temporal gaps in the observational coverage for ${ }^{129}$ I that may be closed by a numerical model simulation if it can be shown that the model results are consistent with the available field data. This combination of observation and numerical modeling is the approach adopted in the present investigation.

[3] The ${ }^{129}$ I tracer plume follows the coastal flow from Sellafield and La Hague into the North Sea and is transported northward with the Norwegian Coastal Current (NCC) while mixing with the Norwegian Atlantic Current (NwAC) on its western flank [Gascard et al., 2004; Orre et al., 2009].

[4] The flow of tracer-labeled AW bifurcates in the eastern Norwegian Sea with one branch flowing northward as the West Spitsbergen Current and the other flowing into the 


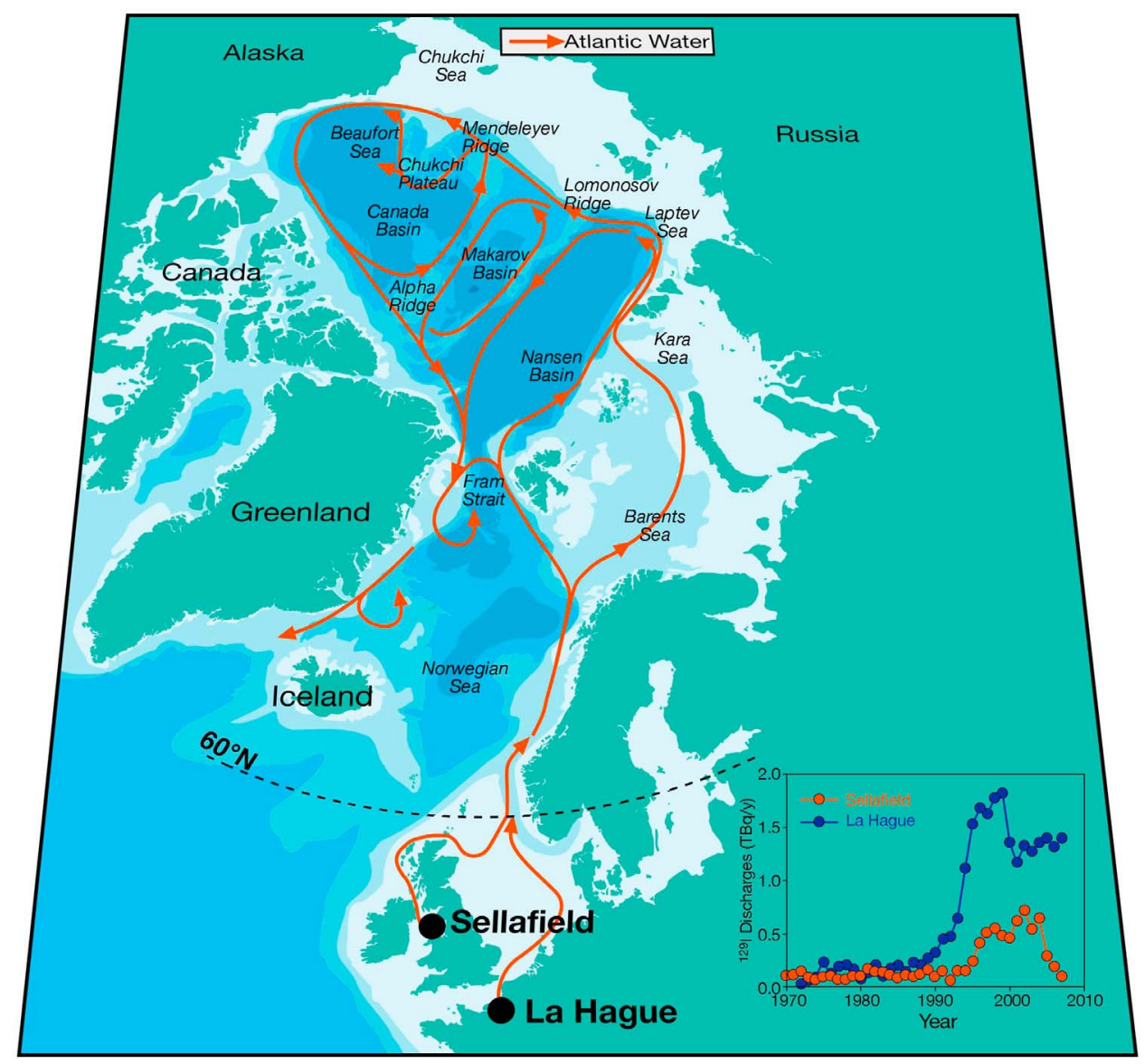

Figure 1. Radionuclide tracers discharged from Sellafield and La Hague are transported northward through Fram Strait and the Barents Sea into the Arctic Ocean where they circulate at different depth levels, marking water of Atlantic origin. Shown here is the schematic flow from the sources into the Arctic Ocean and its continuation at mid-depth along the continental margin and the return flow toward Fram Strait along the Lomonosov and Mendeleyev Ridges. Inset shows history of ${ }^{129} \mathrm{I}$ discharges (TBq/y) from Sellafield (red line) and La Hague (blue line).

Barents Sea. The former flows through Fram Strait and continues eastward along the southern margin of the Nansen Basin, termed Fram Strait Branch Water (FSBW), with a shallow $(200-300 \mathrm{~m})$ core distinguished by a temperature maximum. The other branch experiences cooling and freshening as it flows through the Barents and Kara Seas. The lighter variants of this Atlantic-derived water, with admixtures of river runoff and modified by sea ice melt/freeze [Rudels et al., 2004] feeds the surface waters in the Eurasian Basin. It recirculates to Fram Strait with the Transpolar Drift (TPD) on timescales up to a decade [Schlosser et al., 1995; Smith et al., 2011]. The denser fraction of the Atlanticderived water enters the Nansen Basin as Barents Sea Branch Water (BSBW) through the St. Anna Trough where it encounters and undergoes limited mixing with FSBW. The term 'Atlantic-derived' water is used to identify water which is of Atlantic origin, even if strongly modified as at the surface. The term AW in the Arctic Ocean is reserved for the water in the Atlantic Water Layer (AWL) which occupies the mid-depth or intermediate range below the halocline. In the AWL the branches FSBW and BSBW circulate cyclonically eastward in the boundary current along the continental margins of the Eurasian and Makarov Basins accompanied by bathymetrically steered flows returning along the Lomonosov and Mendeleyev Ridges toward Fram Strait where they merge in outflowing Arctic Intermediate Water (arrows, Figure 1) [Rudels et al., 1994]. The Arctic pathways for the AW at mid-depth were inferred from the analysis of hydrographic observations [Rudels et al., 1994] and were subsequently confirmed by observations [e.g., Carmack et al., 1995; Rudels et al., 1999; Swift et al., 1997] and model results [Holland et al., 1996; Karcher and Oberhuber, 2002; Karcher et al., 2003]. However, numerous questions remain unresolved with respect to the stability of surface and intermediate water circulation and its functional relationship with climate forcing.

[5] Below we introduce results from a model simulation of ${ }^{129}$ I discharges from the two point sources and illustrate their subsequent dispersion in the Arctic and North Atlantic Oceans from 1970 to 2010 . We describe the model set-up and observational data methods used and then compare the model results with ${ }^{129}$ I measurements for the $1990 \mathrm{~s}$ and $2000 \mathrm{~s}$. We use this comparison to characterize the agreement between model and observational results in the context of the major features of the Arctic Ocean circulation at surface and intermediate layer depths. We draw attention to the variable 
pathways of Atlantic and Pacific derived water and propose a new circulation regime for the post-2004 period, which has significant implications for the future export of water to the North Atlantic.

\section{Methods}

\section{1. ${ }^{129}$ I Measurements}

[6] One liter water samples were collected for ${ }^{129}$ I analyses in PVC bottles from a wide range of surface vessels and U.S. Navy nuclear submarines [Smith et al., 1998, 1999, 2011]. Sampling was conducted from submarines by the collection of water through the hull of the vessel and from temporary ice camps established on the surface of the ice by submarine personnel during a series of Scientific Ice Expeditions (SCICEX) between 1995 and 2003. Samples from the 2009 Switchyard program [Smethie et al., 2011] proximal to the Alpha-Mendeleyev Ridge were collected using water bottles lowered through the ice accessed using 'Twin Otter' aircraft. ${ }^{129} \mathrm{I}$ analyses were performed on the $1 \mathrm{~L}$ samples by accelerator mass spectrometry [Kilius et al., 1994] at the IsoTrace Laboratory at the University of Toronto. The sample data were normalized to IsoTrace Reference Material \#2 $\left({ }^{129} \mathrm{I} /{ }^{127} \mathrm{I}=\right.$ $1.174 \times 10^{-11}$ atom ratio). The blank (KI carrier added to distilled water) for this procedure is $0.75 \pm 0.10 \times 10^{7}$ at $/ 1$ and the standard deviation ranged from 5 to $10 \%$ [Edmonds et al., 1998].

\subsection{Model Description}

[7] The applied circulation model is NAOSIM (North Atlantic-Arctic Ocean-Sea Ice Model), a regional, coupled sea ice-ocean model developed at the Alfred Wegener Institute for Polar and Marine Research [Köberle and Gerdes, 2003]. It is derived from the Geophysical Fluid Dynamics Laboratory modular ocean model MOM-2 [Pacanowski, 1995] and a dynamic-thermodynamic sea ice model with a viscous-plastic rheology [Hibler, 1979]. NAOSIM has been used in a number of studies on the dynamics of northern high latitude oceans [e.g., Gerdes et al., 2003; Kauker et al., 2003; Karcher et al., 2003). It has also been previously applied to studies of the dispersion of tracers [Gerdes et al., 2001; Karcher et al., 2004, 2006]. The version used here has 30 unevenly spaced levels in the vertical, starting from $20 \mathrm{~m}$ thickness down to $100 \mathrm{~m}$ depth with the thickness gradually increasing with depth. The model domain includes the Arctic Ocean, the Nordic Seas and the Atlantic Ocean north of approximately $50^{\circ} \mathrm{N}$.

[8] In contrast to the set-up presented in Köberle and Gerdes [2003], an open Bering Strait is introduced for which a constant net volume inflow from the Pacific Ocean of $0.8 \mathrm{~Sv}$ has been applied. At the southern boundary and in the Bering Strait, open boundary conditions have been implemented following Stevens [1991], thereby allowing the outflow of tracers and the radiation of waves. The initial hydrography in January 1948 is adopted from the PHC winter climatology [Steele et al., 2001], while a yearly mean climatology is used as a reference for surface salinity restoring on a time scale of 180 days. The restoring of sea surface salinity is a common method used to prevent the ocean salinity from drastically drifting away from the observed ocean state [Steele et al., 2001]. Sea surface salinity restoring compensates for a mismatch between freshwater forcing data (e.g., precipitation and runoff) and model physics. In the absence of restoring the model drift is arbitrary, depending on the combination of forcing data set and model physics.

[9] Parameterization of river runoff is employed using negative salt fluxes proportional to seasonal climatologies of runoff for each of the major rivers which follows the AOMIP protocol [Holloway et al., 2007]. The model is driven with daily atmospheric forcing from 1948 to 2010 (NCEP/NCAR reanalysis [Kalnay et al., 1996]). The tracer release experiment begins in January, 1970, following an initial model run with zero ${ }^{129}$ I releases from January, 1948 to December, 1969.

[10] Tracer inputs consist of yearly mean ${ }^{129} \mathrm{I}$ discharges from the nuclear reprocessing facilities at Sellafield and La Hague (Figure 1, inset) which are distributed on three adjacent surface boxes of the model in the vicinities of the respective reprocessing facilities. The Sellafield facility produced similar ${ }^{129}$ I discharges as La Hague until the mid1980s with La Hague discharging greater quantities thereafter. The total releases were almost constant in the 1970s, followed by a small peak in the mid-1980s of about $500 \mathrm{GBq} / \mathrm{y}$. A steep increase in the ${ }^{129} \mathrm{I}$ discharges occurred in the early 1990 s reaching a maximum of $2400 \mathrm{GBq} / \mathrm{y}$ in $1998-1999$; a tenfold increase compared to discharges during the 1970s. The total discharges were reduced to levels of about $1500 \mathrm{GBq} / \mathrm{y}$ during the 2000s.

\section{Results}

\subsection{Model Comparison With ${ }^{129}$ I Measurements in the 1990s}

[11] To assess the accuracy of model simulations of ${ }^{129}$ I transport through the Arctic Ocean, a quasi-synoptic data set of ${ }^{129} \mathrm{I}$ measurements from the mid-1990s covering large parts of the central Arctic Ocean is compared to model results in Figures 2-5. The ${ }^{129} \mathrm{I}$ data set is derived from the collection of water samples from icebreaker [Carmack et al., 1997; Smith et al., 1998] and nuclear submarine expeditions [Smith et al., 1999]. In 1995 and 1996 as part of the SCICEX program, the eastern Canadian, the Makarov and parts of the Eurasian Basins were sampled at three depth levels (corresponding to submarine standard operating depths); the Polar Mixed Layer, the halocline and the upper AWL at $59 \mathrm{~m}, 134 \mathrm{~m}$ and $240 \mathrm{~m}$, respectively. The 129I results in Figures 2-4 illustrate the lateral distribution of 129I about 25 years after initial releases into European waters and show the extent to which Atlantic-derived water had spread across the Arctic Ocean.

[12] The most remarkable feature revealed by those measurements was a strong front in the Polar Mixed Layer (0-59 m depth) crossing the Arctic from the western Chukchi Plateau to the northwestern Eurasian Basin, just north of Greenland (Figure 2). Both observations and model results, indicate that the Polar Mixed Layer of the southern and eastern Canadian Basin was largely uncontaminated by nuclear fuel reprocessing inputs of ${ }^{129}$ I. This water was derived from inflow through Bering Strait and was characterized by fallout ${ }^{129}$ I levels of the order of $5 \times 10^{7}$ at/ $/$ that prevailed in surface waters of the Pacific Ocean. Note that in the model simulation no fallout was applied as an additional source, leaving initial and Bering Strait inflow concentrations of ${ }^{129} \mathrm{I}$ at zero. The location of the front between Atlantic and Pacific origin 

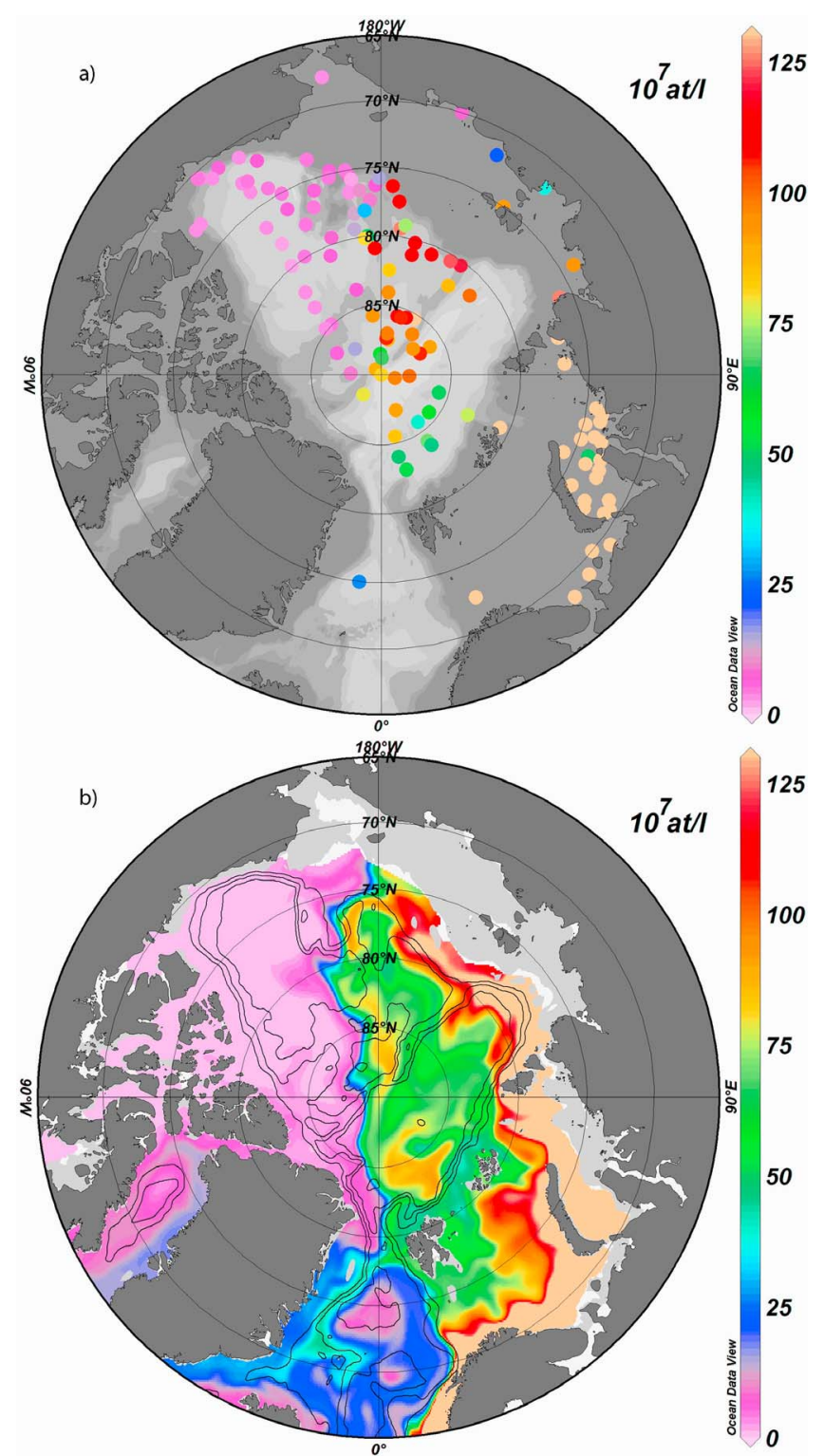

Figure 2. (a) Observed ${ }^{129} \mathrm{I}$ concentrations $\left(10^{7}\right.$ at/l) for surface mixed layer depths (0-59 m) for 1994-1996. (b) Simulated ${ }^{129}$ I distributions $\left(10^{7}\right.$ at/l) at $59 \mathrm{~m}$ for September 1995 are in good agreement with 1994-1996 data sets above and illustrate the eastward spread of high ${ }^{129}$ I labeled, Atlanticorigin surface water across the Makarov Basin to the Chukchi Plateau.

water and the measured concentrations of ${ }^{129} \mathrm{I}$ that characterize this front are accurately simulated by the model. The front outlines the position of the TPD which extended from the Chukchi Sea across the North Pole to Fram Strait in 1995 , approximately following the $0^{\circ}-180^{\circ}$ axis of longitude. Some of the more subtle features of the simulation cannot be resolved with the observational data, although this may simply reflect the fact that the timing of these measurements did not coincide with the development of rapidly changing flow structures.

[13] By 1995, ${ }^{129}$ I concentrations in the surface mixed layers on the continental shelves of the Barents, Kara and Laptev Seas had increased to values in excess of $100 \times 10^{7}$ at/l (Figure 2a) [Josefsson, 1998; Smith et al., 1998; Raisbeck and Yiou, 2002] following the enhanced inputs from the European reprocessing facilities in the early 1990s (Figure 1, inset). This observational feature is clearly delineated in the model results (Figure 2b). The relatively low ${ }^{129} \mathrm{I}$ concentrations $\left(<50 \times 10^{7} \mathrm{at} / \mathrm{l}\right)$ in the southern Nansen Basin in both the observational (Figure 2a) and model (Figure $2 b$ ) results show that surface water flow directly into the Eurasian Basin from the Barents Sea is minimal and that the dominant flow of surface water is eastward through the chain of Russian shelf seas.

[14] At a depth of $134 \mathrm{~m}$ in the interior halocline, ${ }^{129} \mathrm{I}$ concentrations were lower than those in the mixed layer

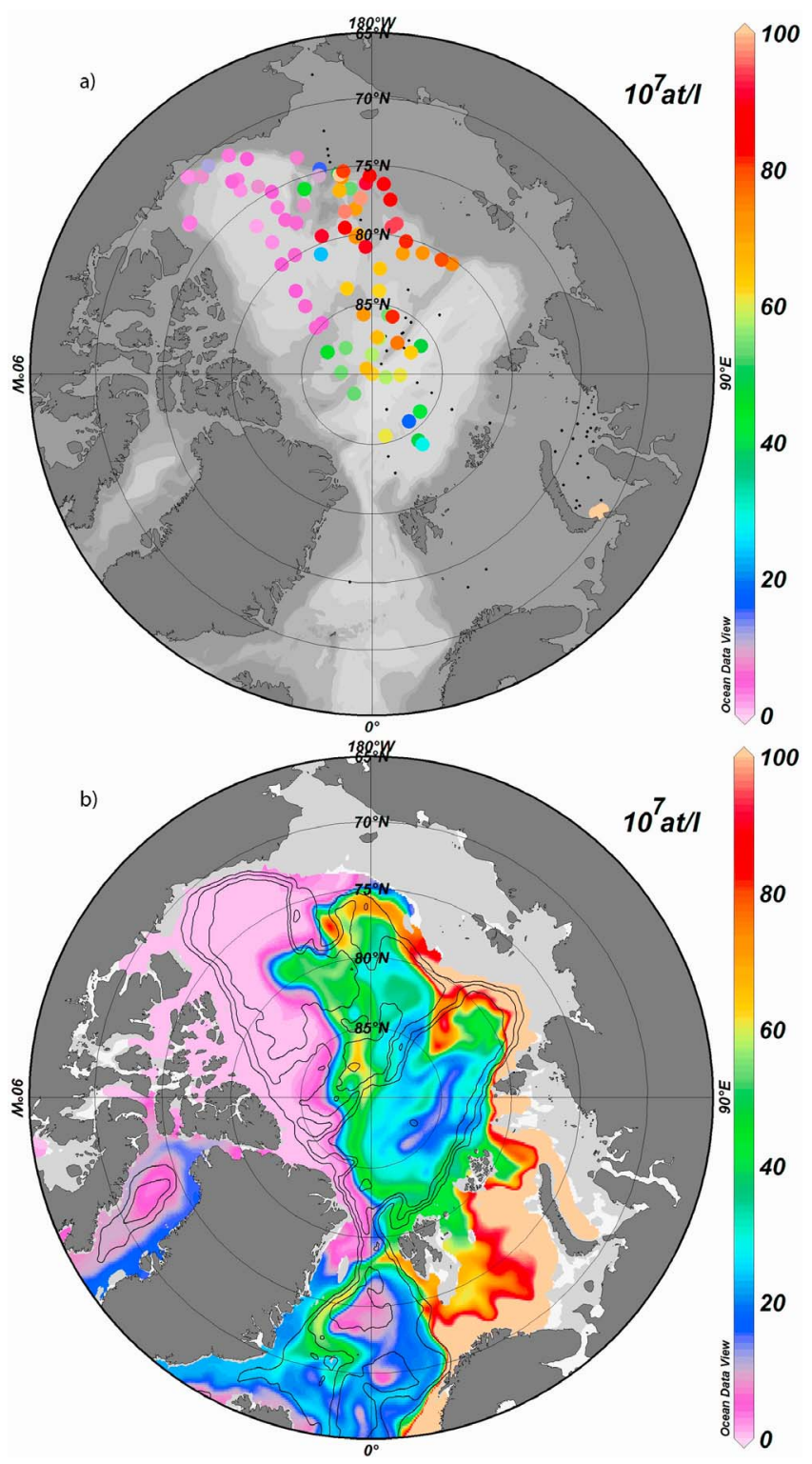

Figure 3. (a) Observed ${ }^{129} \mathrm{I}$ concentrations $\left(10^{7}\right.$ at/l) at a depth of $134 \mathrm{~m}$ for 1994-1996. (b) Simulated ${ }^{129} \mathrm{I}\left(10^{7} \mathrm{at} / \mathrm{l}\right)$ at134 $\mathrm{m}$ for September, 1995 conform to measurements above and show the eastward spread of Atlantic halocline water across the Mendeleyev Ridge into the Canada Basin. 

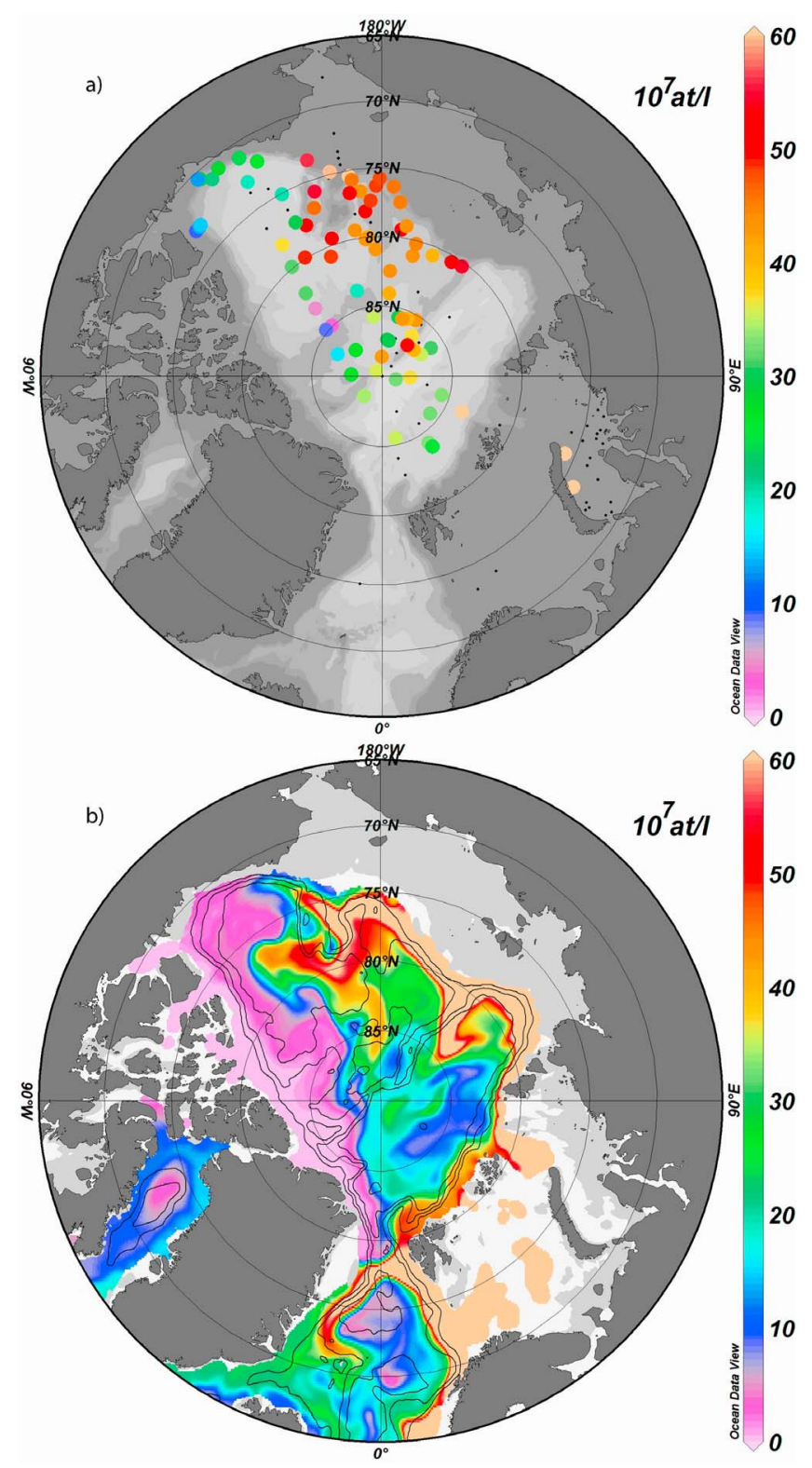

Figure 4. (a) Observed ${ }^{129} \mathrm{I}$ concentrations $\left(10^{7}\right.$ at/l) at a depth of $240 \mathrm{~m}$ for $1994-1996$. (b) Simulated ${ }^{129} \mathrm{I}\left(10^{7}\right.$ at $\left./ \mathrm{l}\right)$ at a depth of $240 \mathrm{~m}$ (Sept., 1995) are in good agreement with measured values above and show the advance of high ${ }^{129}$ I labeled, upper AW into the Canada Basin.

for both measured (Figure 3a) and model results (Figure 3b). The front separating the low ${ }^{129} \mathrm{I}$ levels in Pacific-origin water and the elevated ${ }^{129} \mathrm{I}$ levels $\left(>50 \times 10^{7}\right.$ at/l) in Atlanticorigin water had been displaced eastward toward the Canada Basin compared to its position at a depth of $59 \mathrm{~m}$. The highest ${ }^{129}$ I levels $\left(>100 \times 10^{7}\right.$ at $\left./ \mathrm{l}\right)$ were observed over the southern Makarov Basin and Chukchi Plateau. The simulated ${ }^{129}$ I concentrations for 1995 were marginally lower than the observations in this area, which were made over the period of 1994-1996. Differences between the model simulation and the observations are to be expected, given the large horizontal and vertical gradients in the ${ }^{129} \mathrm{I}$ distributions in this region and the relatively low spatial and temporal sampling densities. The model results show higher ${ }^{129}$ I values for upstream regions over the Siberian continental slope, north of the Laptev Sea where the Lomonosov Ridge joins the continental slope. This high ${ }^{129}$ I water spreads into the southern Makarov Basin and along the Lomonosov Ridge about a year later, thereby bringing model and experimental ${ }^{129}$ I results into good agreement. This suggests that one cause for the relatively small differences between the model and experimental results may be a slightly slower advection in the model as compared to that which actually prevailed during this time period. Observations and model results both show the presence of a flow branch carrying radionuclides into the interior of the Canada Basin from the northern edge of the Chukchi Plateau, as previously noted in several tracer studies [Smith et al., 1999; Smethie et al., 2000].

[15] At a water depth of $240 \mathrm{~m}$, corresponding to upper AWL, the eastward progression of the ${ }^{129}$ I tracer distribution is very pronounced in both the observations and simulation (Figures $4 \mathrm{a}$ and $4 \mathrm{~b}$ ). The plume of high ${ }^{129} \mathrm{I}$ concentrations extends in southern and northern branches around the Chukchi Plateau with similar tracer levels and frontal progression evident in model results and observations. High ${ }^{129} \mathrm{I}$ concentrations along the Lomonosov Ridge outline the AW boundary current separating from the continental slope north of the Laptev Sea. Model results and observations at $240 \mathrm{~m}$ also show the reservoir of uncontaminated Atlantic Water water having low levels ${ }^{129} \mathrm{I}\left(<1 \times 10^{7}\right.$ at/l) in the eastern Canada Basin, north of the Canadian Archipelago. Observations indicate a similar behavior from two stations south of the Alpha Ridge. During the 1990s, the simulation shows that this water was undergoing cyclonic recirculation along the Canadian side of the Alpha Ridge and past Greenland toward Fram Strait as previously inferred from mean age calculations based on applications of transit time distributions (TTDs) to ${ }^{129}$ I and CFC transient tracer measurements [Smith et al., 1999; Smethie et al., 2000; Tanhua et al., 2009].

[16] An ${ }^{129}$ I section from Alaska to Svalbard through the Canada Basin based on results from submarine and icebreaker missions in 1994-1996 [Smith et al., 2011] is compared to the model ${ }^{129}$ I section for 1995 in Figure 5. High ${ }^{129} \mathrm{I}$ concentrations in the upper $200 \mathrm{~m}$ in the Eurasian Basin reflect the return flow of Atlantic-origin surface and halocline water toward Fram Strait within the TPD. The model simulation also shows a core of water entering with Fram Strait Branch Water (FSBW) on the northern slope of Svalbard centered at 300-500 m depth, which carries elevated ${ }^{129}$ I concentrations $\left(>50 \times 10^{7}\right.$ at/l) associated with the early 1990s increase in the ${ }^{129} \mathrm{I}$ input function (Figure 1, inset). Lower concentrations over the Lomonosov Ridge at FSBW depths indicate that the early $1990 \mathrm{~s}^{, 129}$ I increase had not yet arrived at the North Pole by 1995. As noted in the previous paragraph both observed and model results show extremely low ${ }^{129} \mathrm{I}$ levels $\left(<1 \times 10^{7}\right.$ at/l) in intermediate water in the interior of the Canada Basin south of the Alpha Ridge, a feature associated with the high mean age of this water mass [Smith et al., 1999; Smethie et al., 2000]. Both the core of the AW branch separating from the boundary current north of the Chukchi Plateau and ventilating the interior of the Canada Basin and the downstream core of the boundary current flowing eastward along the continental slope are evident as local maxima with ${ }^{129}$ I concentrations of $20-40 \times 10^{7}$ at $/ 1$ in both the measured and simulated 


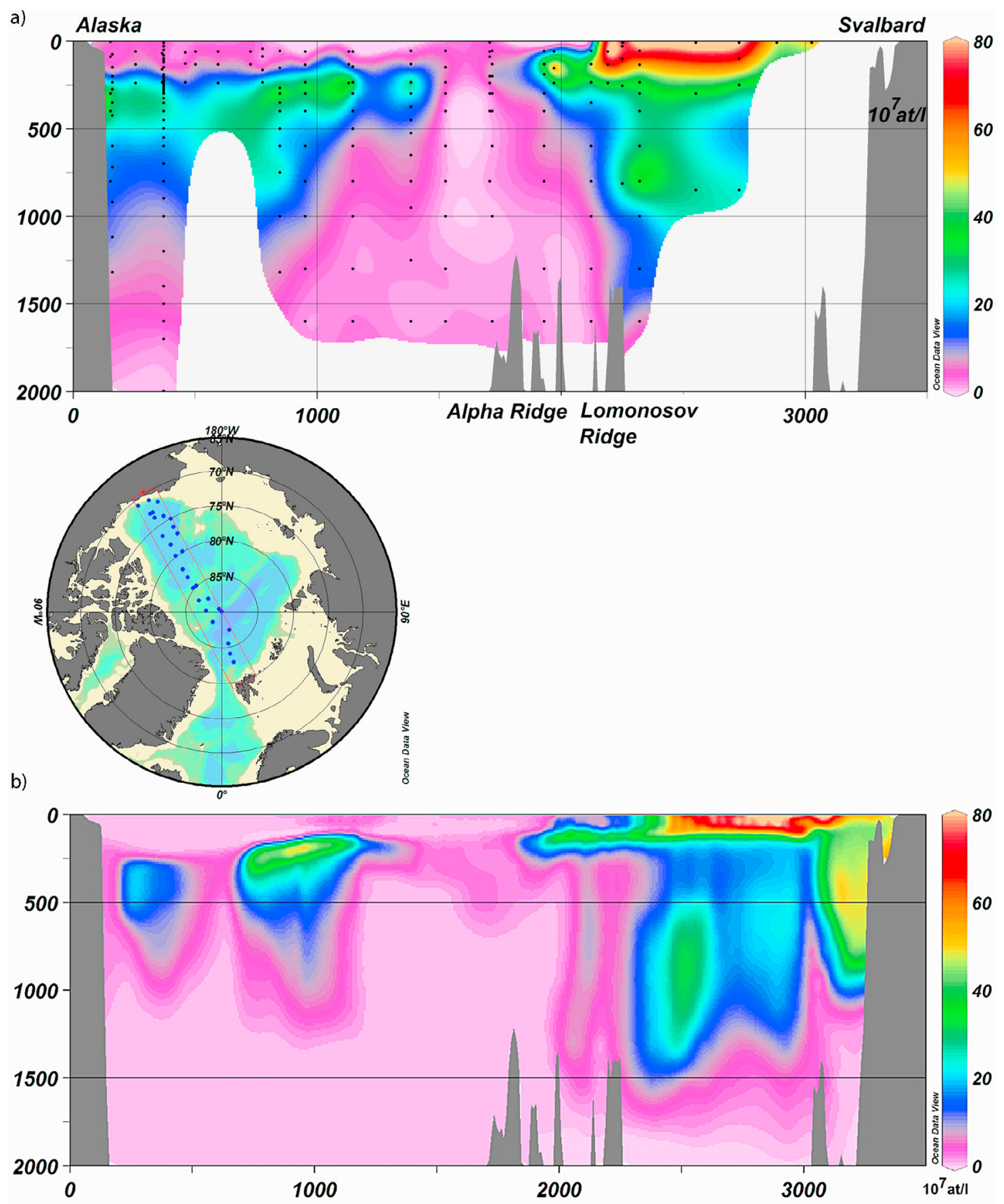

Figure 5. (a) Observed ${ }^{129} \mathrm{I}$ concentrations $\left(10^{7}\right.$ at/l) on a section from Alaska to Svalbard for 19941996. (b) Simulated ${ }^{129} \mathrm{I}\left(10^{7}\right.$ at/l) on Alaska-Svalbard section from 1995 . Both panels similarly show cores of recirculating water of Atlantic origin labeled with high ${ }^{129} \mathrm{I}$ at mid depths.

sections. The observations and model simulation also indicate the presence of a second ${ }^{129} \mathrm{I}$ maximum in the lower AWL (500 m-1000 m) over the Eurasian Basin flank of the Lomonosov Ridge. The horizontal pattern of ${ }^{129} \mathrm{I}$ concentrations at $600 \mathrm{~m}$ depth (Figure 6) indicates that the source for this ${ }^{129}$ I maximum is Barents Sea Branch Water (BSBW) which has entered the southern Nansen Basin via the St. Anna Trough and separated from the AW boundary current north of the Laptev Sea. This feature is replicated in the model simulation by an ${ }^{129} \mathrm{I}$ maximum of similar magnitude $\left(30-40 \times 10^{7}\right.$ at/l) to observed values centered at about $1000 \mathrm{~m}$. Generally, the concentrations and structural features of the simulated ${ }^{129} \mathrm{I}$ distributions are close to those of the measurements. One important difference occurs at depths below $1000 \mathrm{~m}$ in the Canada Basin, where measured ${ }^{129} \mathrm{I}$ levels of $5-10 \times 10^{7}$ at/l are higher than model values of $0-5 \times 10^{7}$ at $/ 1$. It is possible that the observed values at this depth carried a contribution from fallout or other unidentified sources from earlier time periods which have not been included in the model input function. It is also possible that 


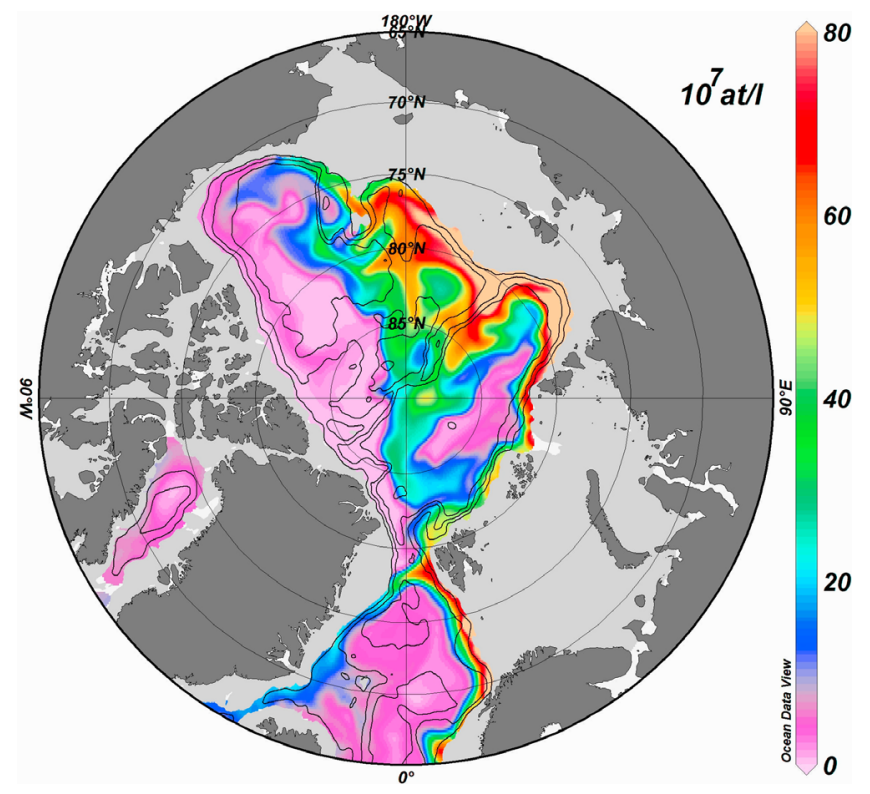

Figure 6. Simulated ${ }^{129}$ I concentrations $\left(10^{7}\right.$ at/l) at a depth of $600 \mathrm{~m}$ for September, 1995 show elevated levels extending along the continental slope to the Barents Sea indicating that ${ }^{129} \mathrm{I}$ maximum at $600-800 \mathrm{~m}$ in Eurasian Basin (Figure 5) is associated with Barents Sea Branch Water (BSBW).

the magnitude of dense water formation in the model is insufficient to simulate actual ${ }^{129} \mathrm{I}$ concentrations below $1000 \mathrm{~m}$. In principle this latter possibility can be examined using additional tracers.

[17] In summary, the three dimensional distribution of ${ }^{129} \mathrm{I}$ in the Arctic Ocean basins, as characterized by quasisynoptic measurements in the mid-1990s, is well described by the model simulation. Given that the ${ }^{129} \mathrm{I}$ input function had a strong increase in the early 1990s, these results also indicate that the advective time scales for the model circulation are realistic within an uncertainty of about one year.

\section{2. ${ }^{129}$ I Dispersion With a Variable Arctic Ocean Circulation}

\subsubsection{Surface Mixed Layer}

[18] The temporal evolution of the simulated ${ }^{129}$ I dispersion in surface water from the 1980s to the late 2000s is illustrated in Figure 7. In the mid-1980s, the surface water (upper $20 \mathrm{~m}$ ) dispersion of the tracer was mainly confined to the coastal waters of the Norwegian, Barents and Kara Seas (Figure 7a). However, following passage through the outer Laptev Sea, a filament of ${ }^{129} \mathrm{I}$ enriched $\left(>100 \times 10^{7}\right.$ at/l), shelf water entered the Eurasian Basin along the continental slope (Figure 7a). This tracer signal outlined the pathway for Arctic shelf water that supplied the TPD as it flowed from the Laptev Sea across the North Pole toward Fram Strait. The flow of ${ }^{129} \mathrm{I}$ toward Fram Strait at this time was comparatively small because significant quantities of ${ }^{129} \mathrm{I}$ had been discharged from the nuclear fuel reprocessing plants only since the mid-1970s and at least 10 years were required for the transport of surface water from the North Sea to the North Pole [Smith et al., 2011].
[19] This basic circulation regime was maintained until the late 1980s, when large changes in the oceanic circulation pattern were initiated as a consequence of an abrupt increase of the Arctic Oscillation (AO) index in 1989 (J. Overland et al., Atmosphere, 2008; see http://www. arctic.noaa.gov/report08/atmosphere.html) and a coincident switch of the oceanic circulation regime in the Canadian Basin [Proshutinsky and Johnson, 1997; Proshutinsky et al., 2009] from 'anti-cyclonic' (1985-88) to 'cyclonic' (19891996). During this period the size of the Beaufort Gyre was reduced and the Siberian river runoff was diverted eastward from its previous direct pathway into the TPD [Steele and Boyd, 1998]. In addition, the boundary between Atlanticderived and Pacific-derived water was shifted farther into the Canadian Basin toward the Mendeleyev Ridge and the Chukchi Plateau. Below the halocline, anomalously warm water of Atlantic origin entered the Makarov Basin along the Siberian slope [Carmack et al., 1997] providing a temperature anomaly that has been subsequently traced throughout the Arctic Ocean [McLaughlin et al., 2009]. Model simulations with NAOSIM are largely consistent with these observations [Karcher et al., 2003; Gerdes et al., 2003]. In particular, the ${ }^{129}$ I dispersion simulated in the present experiment reflects this changing circulation pattern. In the 1990s, Atlantic-derived water marked with high ${ }^{129}$ I concentrations flowed farther across the Lomonosov Ridge into the Makarov and Canadian Basins as is evident in a comparison of the surface distributions of ${ }^{129} \mathrm{I}$ in 1985 (Figure 7a) and 1990 (Figure 7b). The change in the surface flow fields in the Arctic became fully developed by the mid-1990s (Figure 7c). In this phase the Beaufort Gyre had shrunk to a comparatively small size and the axis of the TPD had shifted from the western Laptev Sea to the East Siberian and Chukchi Seas. A novel feature observed in 1995 and present in the ${ }^{129} \mathrm{I}$ simulation was the displacement of Pacificderived water into the western part of the East Siberian Sea by Atlantic-derived water (Figure 7c).

[20] By 2000, a re-establishment of the position of the TPD along the Laptev Sea - Fram Strait axis and an enlargement of the Beaufort Gyre had occurred, as documented by hydrography [Björk et al., 2002; Steele et al., 2004; Morison et al., 2006; Alkire et al., 2007]. These changes followed a reduction of the AO index to low positive values after its high phase in 1989-1995 and are also reflected in the simulated distribution of ${ }^{129} \mathrm{I}$ in surface waters (Figure $7 \mathrm{~d}$ ). Atlantic-derived water with elevated ${ }^{129}$ I levels $\left(>125 \times 10^{7}\right.$ at $\left./ 1\right)$ was no longer apparent in the vicinity of the Chukchi Plateau leaving surface concentrations below fallout levels $\left(<5 \times 10^{7}\right.$ at/l). The front between Atlantic-derived and Pacific-derived water shifted from a position in Fram Strait to a position immediately north of Greenland, effectively reducing Fram Strait export options for water from the Canada Basin. Flow on the North American flank of the TPD was interrupted and the outflow of Pacific-origin water through Fram Strait reduced. By 2004, a branch of the TPD had spread off to the west, north of Greenland and the Canadian Archipelago, in accordance with the large scale, anti-cyclonic circulation that prevailed in the Canadian basin throughout the 2000s (Figure 7e). These results are consistent with hydrographic observations 

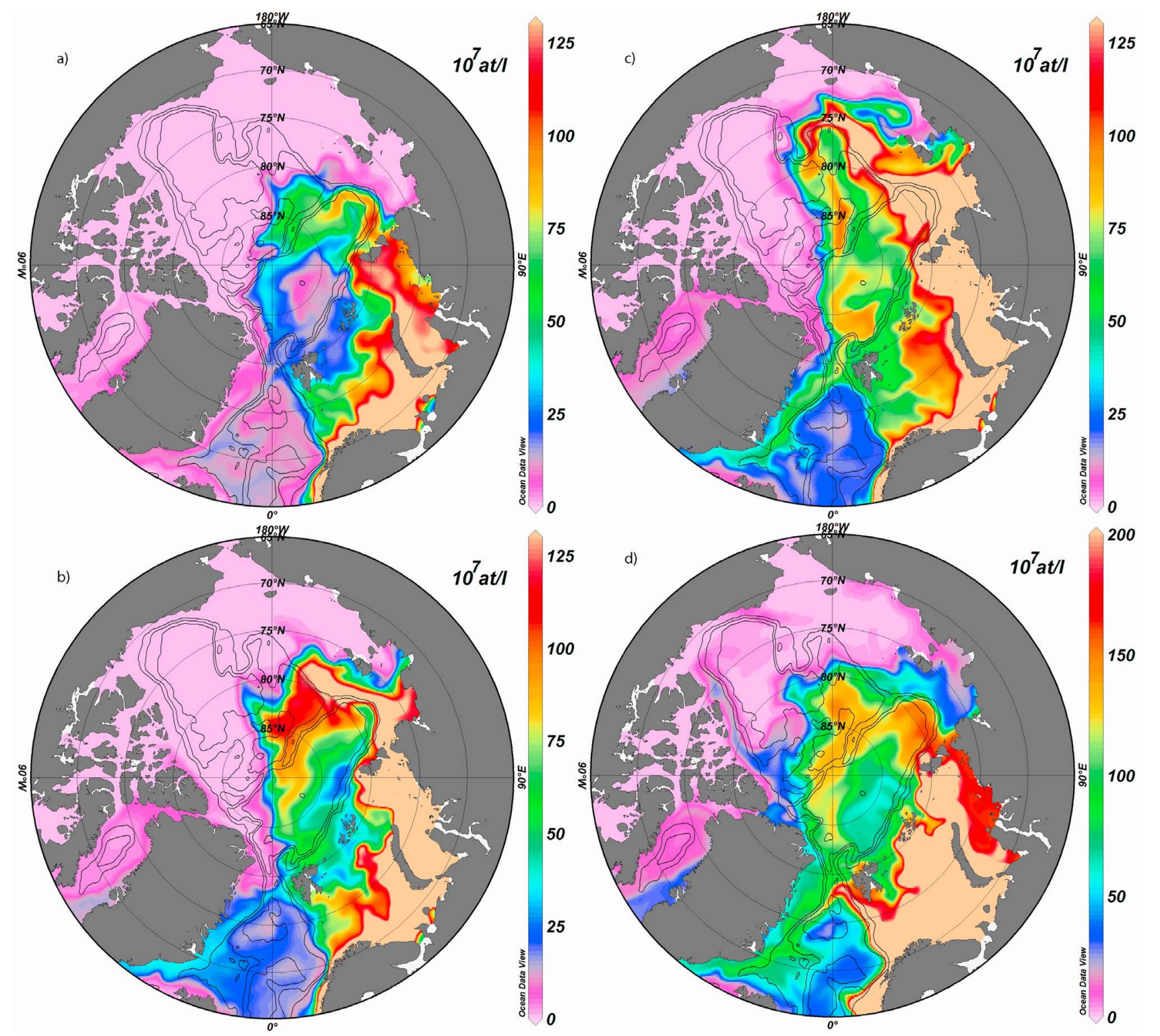

Figure 7. Model concentrations of ${ }^{129} \mathrm{I}\left(10^{7}\right.$ at/l) at the surface in (a) September, 1985, (b) 1990, (c) 1995, (d) 2000, and (e) 2004 illustrate progression of boundary between Atlantic and Pacific-origin water into Canada Basin during high AO regime in 1990s and subsequent return to Lomonosov Ridge during lower AO conditions prevailing after 2004. Please note that since source water concentrations entering the Arctic have changed drastically in time (Figure 1), the scaling has been chosen to differ for each year to exhibit the changing flow patterns.

indicating that Pacific origin water had almost totally disappeared from Fram Strait by 2004 [Falck et al., 2005].

[21] Between the mid and end 2000s, model ${ }^{129}$ I surface concentrations in the Eastern Makarov Basin (Figures 7e and $8 \mathrm{~b}$ ) had decreased to levels well below their values in the mid-1990s (Figure 7c). In contrast, ${ }^{129}$ I levels in the narrow TPD, stretching from the Laptev Sea to northern Greenland, had increased to values of $400-1200 \times 10^{7}$ at $/ 1$. These results are consistent with the hydrographic results of Alkire et al. [2007] showing a partial return of Pacific origin water within the mixed layer and the upper halocline layers, beginning in 2003-2004, to regions in the Makarov Basin previously invaded by Atlantic origin water in the early 1990s. By 2008, the front between Atlantic-derived and Pacific-derived surface water that was aligned with the TPD had shifted back toward the Lomonosov Ridge from its 1990s alignment over the Alpha-Mendeleyev Ridge, signaling a return to the regime that prevailed prior to the early 1990s. Model results for 2008 are supported by ${ }^{129} \mathrm{I}$ measurements from 2007 to 2009 (Figure 8a). By this latter period, ${ }^{129} \mathrm{I}$ levels in the TPD near the North Pole had increased to values in excess of $600 \times 10^{7}$ at/l while ${ }^{129} \mathrm{I}$ levels in the surface mixed layer of the Canada Basin had decreased to the fallout background levels $\left(\cong 5 \times 10^{7}\right.$ at $\left./ 1\right)$ associated with Pacific-origin water. ${ }^{129} \mathrm{I}$ concentrations in the southern Nansen Basin were significantly lower than 


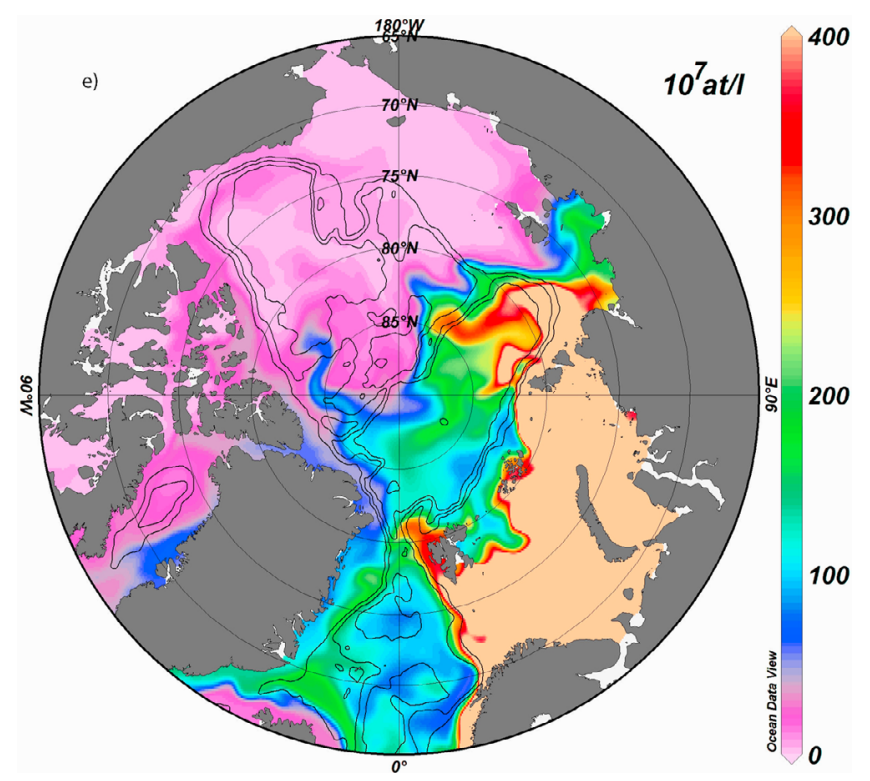

Figure 7. (continued)

those in the TPD in both model and observations for 20072009 (Figures 8a and 8b), again illustrating the extent to which surface water transport into the Arctic Ocean occurs mainly by cyclonic flow through the chain of Russian shelf seas rather than by direct, off-shelf flow from the Barents Sea into the Eurasian Basin.

\subsubsection{Atlantic Layer Water}

[22] During the high AO circulation regime of the mid$1990 \mathrm{~s},{ }^{129}$ I-labeled, AW had progressed eastward at the $240 \mathrm{~m}$ water depth level to a position over the Chukchi Plateau in the model simulation where it encountered low ${ }^{129}$ I water of Pacific origin. In 1995 a continuous plume of AW labeled by elevated ${ }^{129} \mathrm{I}$ concentrations stretched along the continental margin from the Makarov Basin to the Alaskan slope (Figure 5). This feature persisted until about 2004 when ${ }^{129}$ I levels began to decrease along the continental margin as the return flow of high ${ }^{129}$ I-labeled AW water toward Fram Strait along the Lomonosov Ridge intensified (Figures 9a and 9b). By 2008 these changes in circulation had resulted in a westward retreat of the front between Atlantic origin water and water of the Pacific domain at the $240 \mathrm{~m}$ level to a position over the Mendeleyev Ridge (Figure 9c). Particularly significant in the simulation results for 2008 is the absence of a plume of elevated ${ }^{129}$ I flowing along the continental margin south of the Chukchi Plateau. These results show that there was a significant shift in the strength and even flow direction of the AW boundary current in this region between 2004 and 2008. The 2008 model results are supported by the ${ }^{129}$ I data sets from 2007 to 2009 (Figure 9d). The model results indicate that elevated ${ }^{129} \mathrm{I}$ levels in the central Canada Basin were associated with the branching off of a filament of AW from the deep return flow along the Mendeleyev Ridge (Figure 9c). Measured ${ }^{129} \mathrm{I}$ concentrations were slightly higher than simulated values, but ${ }^{129} \mathrm{I}$ levels varied sharply with depth at the $240 \mathrm{~m}$ level, because this depth represented the position of the boundary between upper AW and lower halocline water rather than core AW in the Canada Basin. Model results for core AW at the $500 \mathrm{~m}$ level (Figure 10b) show a distinct filament of elevated ${ }^{129}$ I levels (blue colors versus gray/violet ambient levels) detaching southward from the return flow at $85^{\circ} \mathrm{N}$ and flowing into the interior of the Canada Basin. This is the deep expression of the flow from the Mendeleyev Ridge noted previously. ${ }^{129}$ I levels in the vicinity of the Chukchi Plateau also indicate traces of AW stemming originally from the Makarov basin earlier, however, with much lower concentrations than in the return flow along the Mendeleyev Ridge. This situation is similar to the conditions at $240 \mathrm{~m}$ depth, and is associated with flow separation from the AW boundary current that flows around the northern slope of the Chukchi Plateau and then turns southward along the Northwind Ridge on the eastern flank of the Chukchi Plateau [Smith et al., 1999; Smethie et al., 2000]. The ${ }^{129} \mathrm{I}$

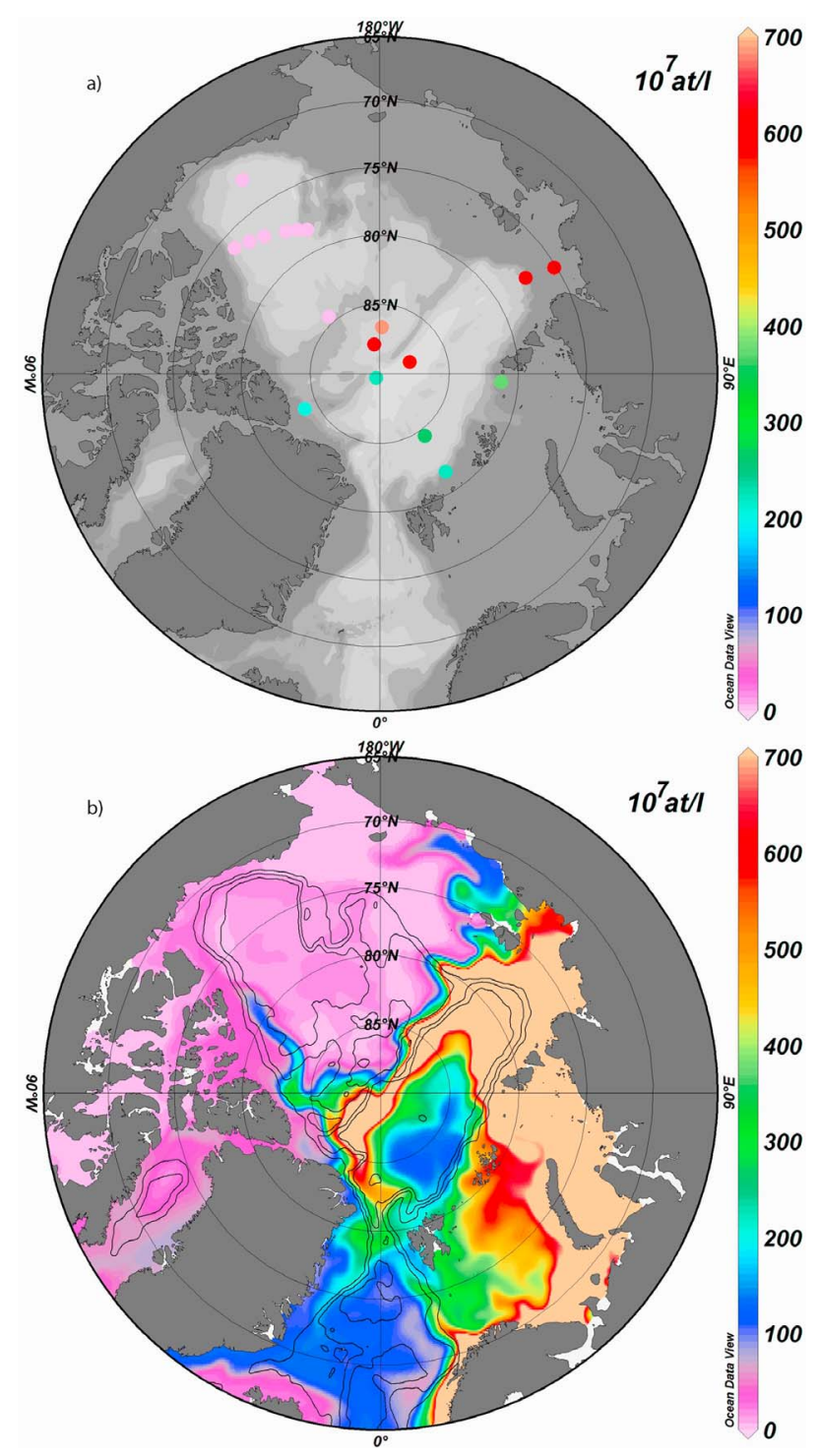

Figure 8. (a) Measured ${ }^{129}$ I surface water concentrations $\left(10^{7}\right.$ at/l) for 2007-2009 from Polarstern (2007), JOIS (2008) and Switchyard (2009) missions. (b) Model ${ }^{129}$ I surface concentrations $\left(10^{7}\right.$ at $\left./ 1\right)$ for September, 2008 delineate flow of Atlantic-origin water along Lomonosov Ridge toward Fram Strait and anticyclonic flow into Canada Basin north of Greenland. 

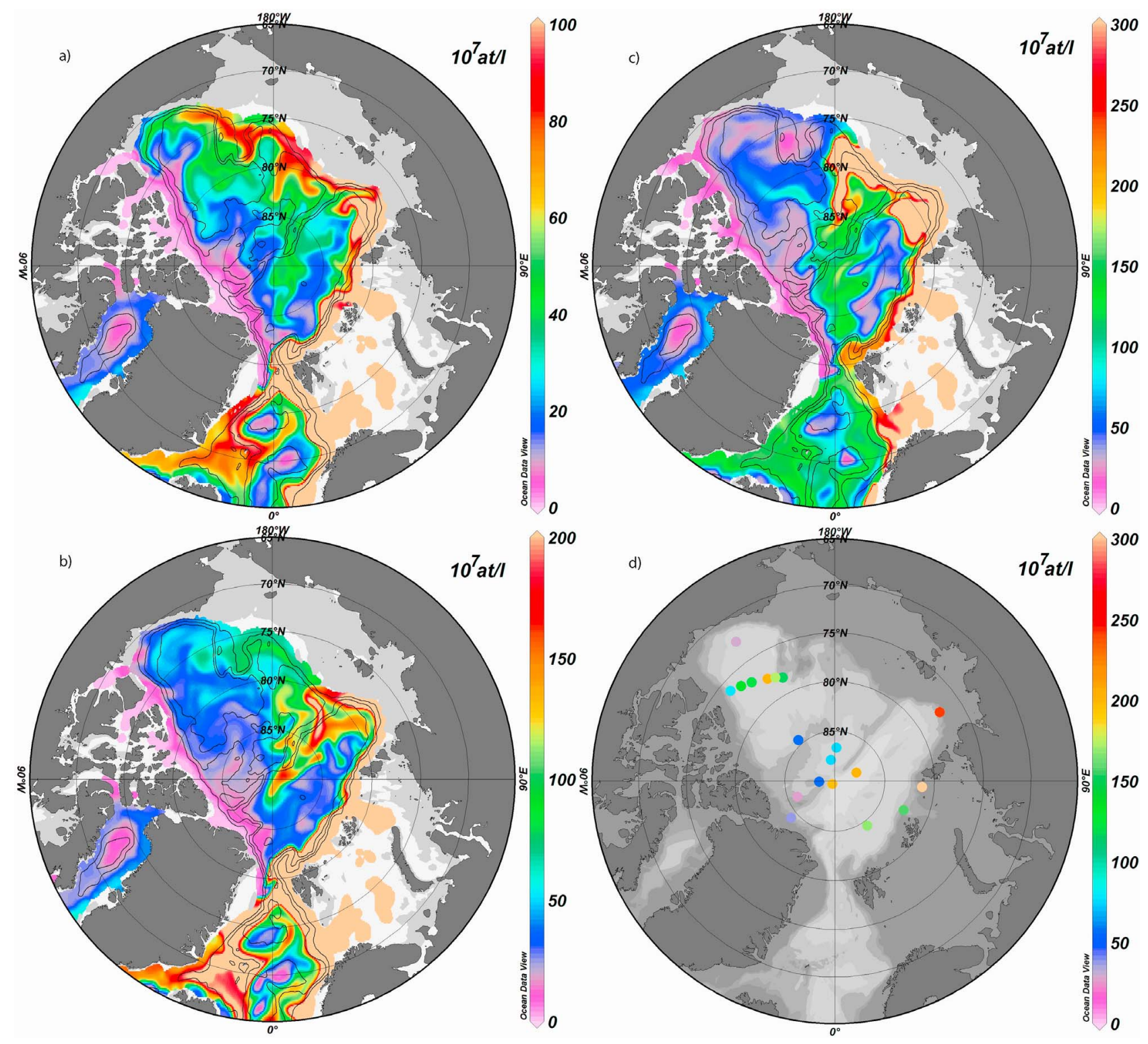

Figure 9. Model results for ${ }^{129} \mathrm{I}\left(10^{7}\right.$ at/l) at the $240 \mathrm{~m}$ depth level in September of (a) 2000, (b) 2004, and (c) 2008 illustrate westward withdrawal of ${ }^{129}$ I labeled, upper Atlantic Water to the Mendeleyev Ridge by 2008 and a general anticyclonic circulation pattern in Canada Basin. (d) Measured ${ }^{129}$ I concentrations $\left(10^{7} \mathrm{at} / \mathrm{l}\right)$ at $240 \mathrm{~m}$ for 2007-2009 support modeled data from 2008 in showing elevated concentrations in the interior Canada Basin and on the Lomonosov Ridge.

observations in this region (Figure 10a) provide no differentiation between the two branches, but they do confirm the presence of elevated ${ }^{129} \mathrm{I}$ levels at $500 \mathrm{~m}$ in the interior of the Canada Basin north of the Chukchi Plateau.

[23] The model results show elevated ${ }^{129}$ I concentrations $\left(>50 \times 10^{7}\right.$ at/l) throughout the entire AWL on the vertical section between Alaska and Svalbard for 2008 (Figure 11). An important exception is the region over the Canada Basin flank of the Lomonosov Ridge where older water having sharply reduced ${ }^{129}$ I levels $\left(<20 \times 10^{7}\right.$ at/l) had apparently recirculated northward from the pool of low tracer water that remained relatively isolated over the Alpha Ridge, a phenomenon also observed during the 1996 USS Pogy cruise. Low concentrations of ${ }^{129} \mathrm{I}$ characterized the entire Polar
Mixed Layer in the Canada Basin extending to the Lomonosov Ridge, thereby outlining the horizontal and vertical dimensions of the surface layer of Pacific-origin water that comprised the Beaufort Gyre. This was also apparent from the surface maps of observed and simulated ${ }^{129} \mathrm{I}$ concentrations in 2008 (Figures $8 \mathrm{a}$ and $8 \mathrm{~b}$ ). In both the measured (Figure 11a) and model results (Figure 11b) the return flow of AW along the Eurasian Basin slope of the Lomonosov Ridge past the North Pole is delineated by a steep ${ }^{129}$ I gradient at intermediate depths of 250-700 m between the Eurasian and Canada Basins. The geographical alignment of this gradient with the Lomonosov Ridge was similar to that observed in 1996, although ${ }^{129}$ I concentrations had increased by approximately a factor of 4 by 2008. Both the position and 

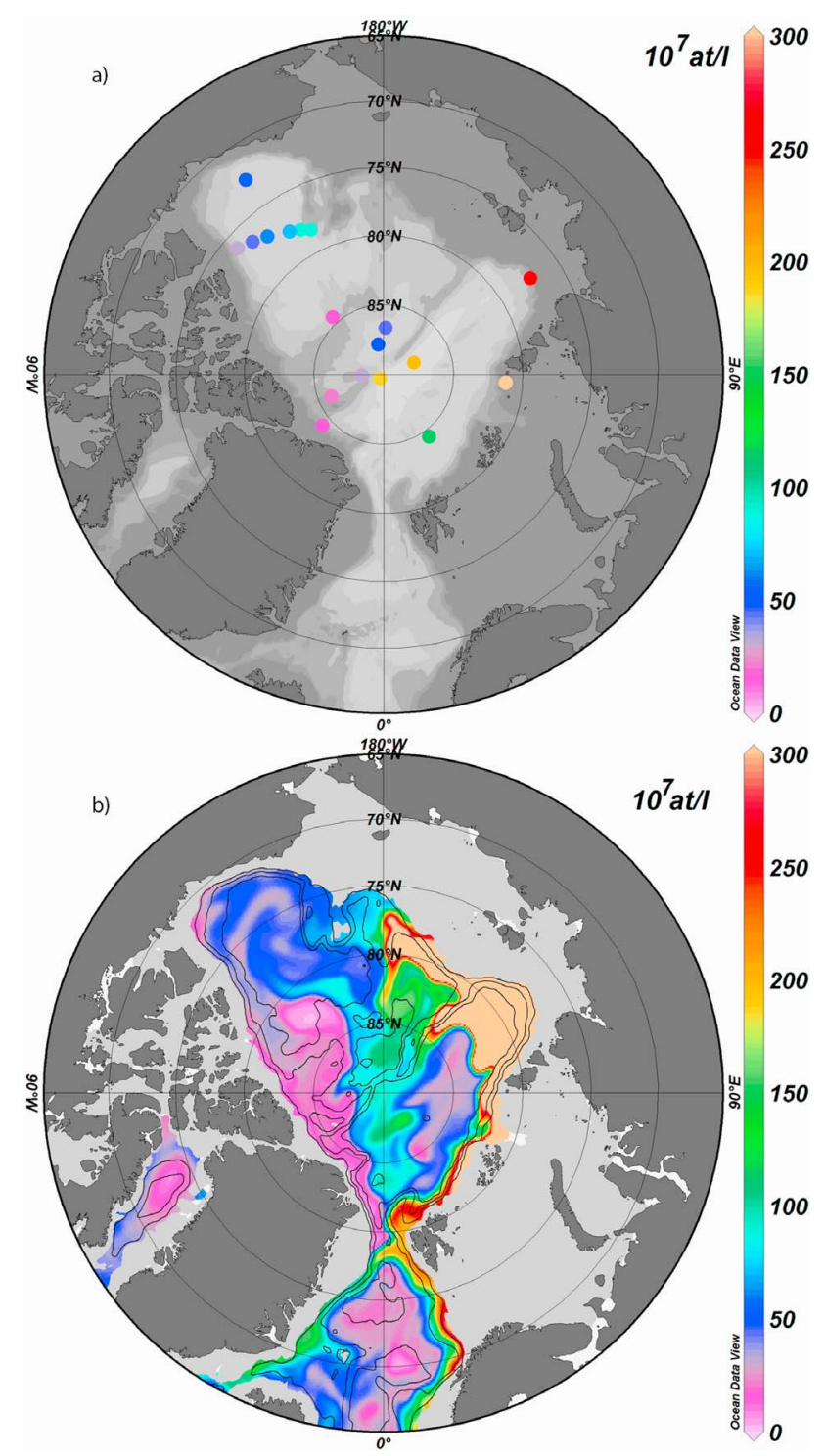

Figure 10. (a) Measured ${ }^{129} \mathrm{I}$ concentrations $\left(10^{7} \mathrm{at} / \mathrm{l}\right)$ at a depth of $500 \mathrm{~m}$ for $2007-2009$. (b) Model ${ }^{129} \mathrm{I}$ concentrations $\left(10^{7}\right.$ at/l) at $500 \mathrm{~m}$ for September, 2008 are in agreement with observed results with respect to elevated concentrations outlining pathways for flow of AW into interior of Canada Basin and along the Lomonosov Ridge.

magnitude of this modeled ${ }^{129}$ I gradient over the Lomonosov Ridge are consistent with the combined observations [Smith et al., 2011] from the Polarstern (2007), JOIS (2008) and Switchyard (2009) missions (Figure 11a). The mid-depth ${ }^{129} \mathrm{I}$ maximum in the Canada Basin from core AW entering the interior from flow separation over the Chukchi Plateau is also evident both in the experimental and simulated results (Figures 11a and 11b), although it is slightly more pronounced in the former.

\subsection{3. ${ }^{129}$ I Time Series Comparisons:}

\section{Model and Measurements}

[24] Although the post-1990s observational coverage of the ${ }^{129} \mathrm{I}$ distribution in the Arctic Ocean was more limited compared to earlier periods, time series measurements extending into the late 2000s permitted a consistency check of the model results. Repeat measurements over the eastern Laptev Sea slope near the Lomonosov Ridge (Figure 12, top), for example, allowed an estimate of the arrival time for the steep increase in the ${ }^{129}$ I signal associated with elevated reprocessing discharges during the 1990s (Figure 1, inset). The model predicted the arrival of the steepest increase in ${ }^{129} \mathrm{I}$ levels to occur in 2003-2007 for both halocline $(60-80 \mathrm{~m})$ and upper Atlantic layer (200-240 m) water. The measured values at that location are in reasonable agreement with model results with the exception of an ${ }^{129} \mathrm{I}$ value above $600 \times 10^{7}$ at $/ 1$ measured in the halocline in 2003 at a time for which the model predicted an ${ }^{129}$ I value about $50 \%$ lower. This single, measured ${ }^{129} \mathrm{I}$ concentration could have been associated with an eddy which advected high ${ }^{129}$ I concentration water from the shelf or may have represented the arrival of the actual tracer front. The horizontal pattern of simulated ${ }^{129}$ I levels showed that in 2003 the front was characterized by levels of $600 \times 10^{7}$ at/l and located at the boundary of the Kara and Laptev Seas. It only approached the eastern Eurasian Basin and Laptev Sea slope in 2004 (Figure 7e). These results characterize the challenges of point-wise comparisons of observations and model results, particularly in the vicinity of strong tracer gradients.

[25] The steep, leading edge of the ${ }^{129}$ I spike associated with enhanced discharges in the 1990s arrived several years later at the North Pole (Figure 12, middle) compared to its arrival time at the slope of the Laptev Sea. Time series measurements of ${ }^{129} \mathrm{I}$ at the North Pole are in reasonably good agreement with model predictions for both halocline and Atlantic Layer Water (Figure 12, middle). The time dependence of ${ }^{129}$ I transport through the halocline over the Mendeleyev Ridge (Figure 12, bottom) differs from that of other locations, because it is strongly affected by changes in the position of the front between Atlantic and Pacific origin water during the 1990s. In the period before the high AO phase of the 1990s, halocline water in this region consisted of Pacific-origin water and ${ }^{129} \mathrm{I}$ levels were low $\left(<5 \times 10^{7}\right.$ at/l). The shift to a high AO phase in the mid-1990s resulted in the spread of Atlantic-origin halocline water over this region labeled by ${ }^{129} \mathrm{I}$ levels in excess of $50 \times 10^{7}$ at $/ \mathrm{l}$. The shift to anti-cyclonic conditions in the 2000s led to the return of Pacific-origin water and accompanying low ${ }^{129} \mathrm{I}$ levels. This sequence of shifts in halocline (and surface water) circulation produced an ${ }^{129}$ I temporal maximum in the model simulation for the ${ }^{129} \mathrm{I}$ time series during the $1990 \mathrm{~s}$, a feature that is also consistent with ${ }^{129} \mathrm{I}$ time series measurements (Figure 12, bottom, blue and magenta). In contrast, ${ }^{129} \mathrm{I}$ levels in underlying Atlantic Water at 200-240 m increased steadily in the simulation through the early 1990s (Figure 12, bottom, green and red), because this water mass was never displaced by Pacific-origin water. ${ }^{129}$ I levels then remained relatively constant until the arrival in 2007 of the large tracer spike associated with enhanced discharges during the 1990s. The modeled and measured ${ }^{129} \mathrm{I}$ time series reflect the tracer responses to changes in atmospheric forcing and consequent shifts in circulation.

\subsection{Interruption of the AWL Boundary Current}

[26] Two different flow features began to develop simultaneously in the mid-2000s: the AW boundary current flowing eastward from the Eurasian Basin via the Makarov Basin along the slope of the Chukchi Sea into the Canada 


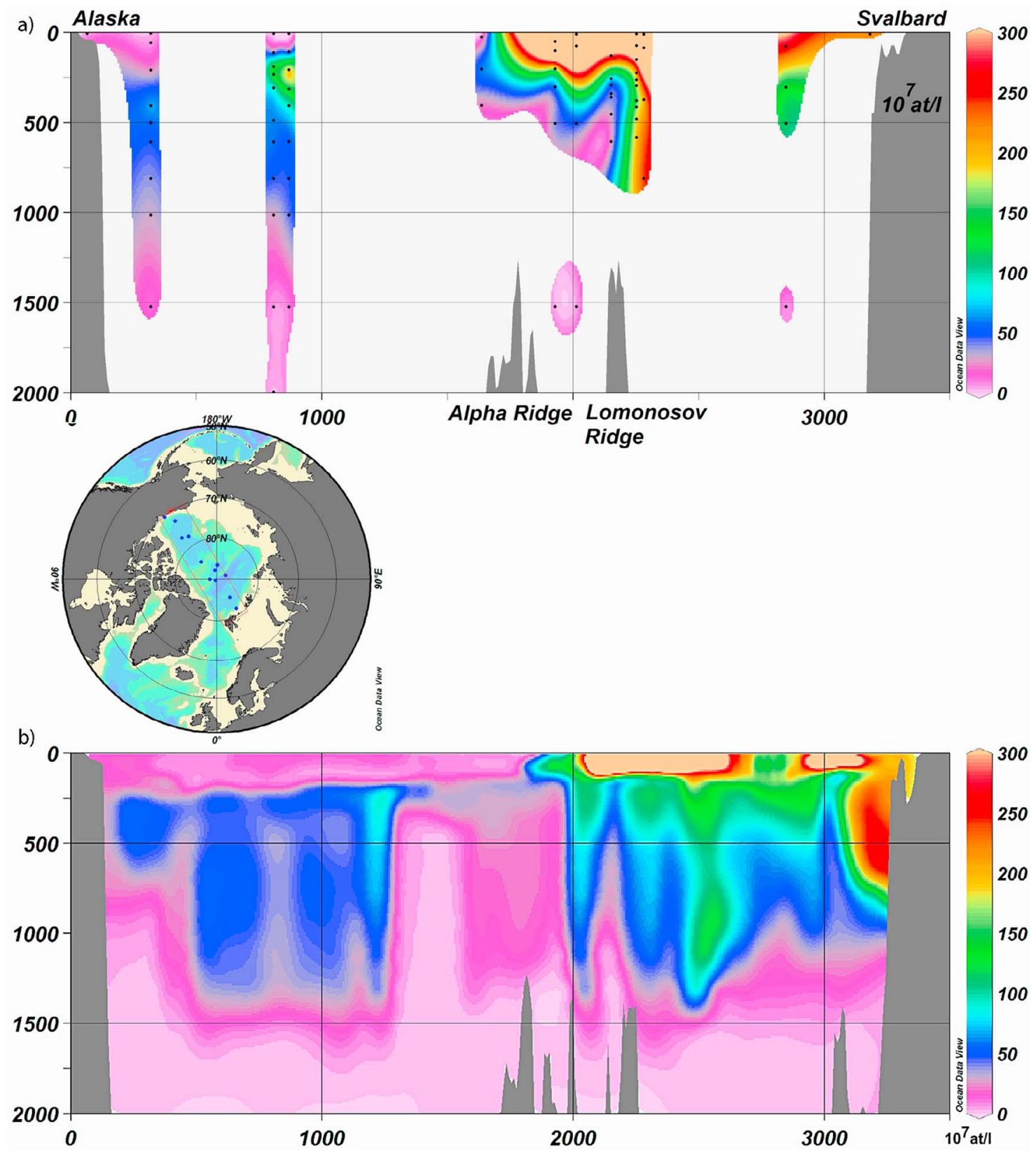

Figure 11. (a) Measured ${ }^{129}$ I concentrations ( $10^{7}$ at/l) for Polarstern (2007), JOIS (2008) and Switchyard (2009) missions. (b) Modeled ${ }^{129}$ I concentrations (10 at/l) in September 2008, on section from Alaska to Svalbard show similarly elevated levels in AW over the Lomonosov Ridge and interior of Canada Basin associated with arrival of ${ }^{129} \mathrm{I}$ input pulse from 1990s.

Basin began to weaken with a corresponding strengthening of the return flow toward Fram Strait along the Mendeleyev Ridge (Figures $9 \mathrm{~b}$ and 9c). This flow pattern is in contrast to the dominant pattern of the 1990 s and early 2000 s, when AW flow crossing the Lomonosov and Mendeleyev Ridges into the Canada Basin and the return flow along the central ridges were of similar strength (Figure 9a). This change in circulation regime was distinguished by a withdrawal of high ${ }^{129} \mathrm{I}$, labeled AW from the Alaskan slope to the Mendeleyev Ridge (compare Figures 9a and 9b). The period of intense AW boundary current transport and high eastward flow velocities on the Alaskan slope, which prevailed in the 1990s and early 2000s, had come to an end by the mid-2000s. The flow of upper AW (200-250 m) actually switched to a westward direction in 2004 (Figure 13, top, light green line) in concert with an intensification of the anti-cyclonic circulation of the Beaufort Gyre in the late 2000s which was characterized by a strong negative anomaly of the curl of the surface velocity (Figure 13, top, black line). At deeper levels the Atlantic Water boundary current at the Alaskan slope continued to circulate eastward, but at strongly reduced velocities compared to those typical of the 1990s (Figure 13, top, red and black lines). The change in circulation regime in the late 2000 s, as is evident from the changes in the simulated 

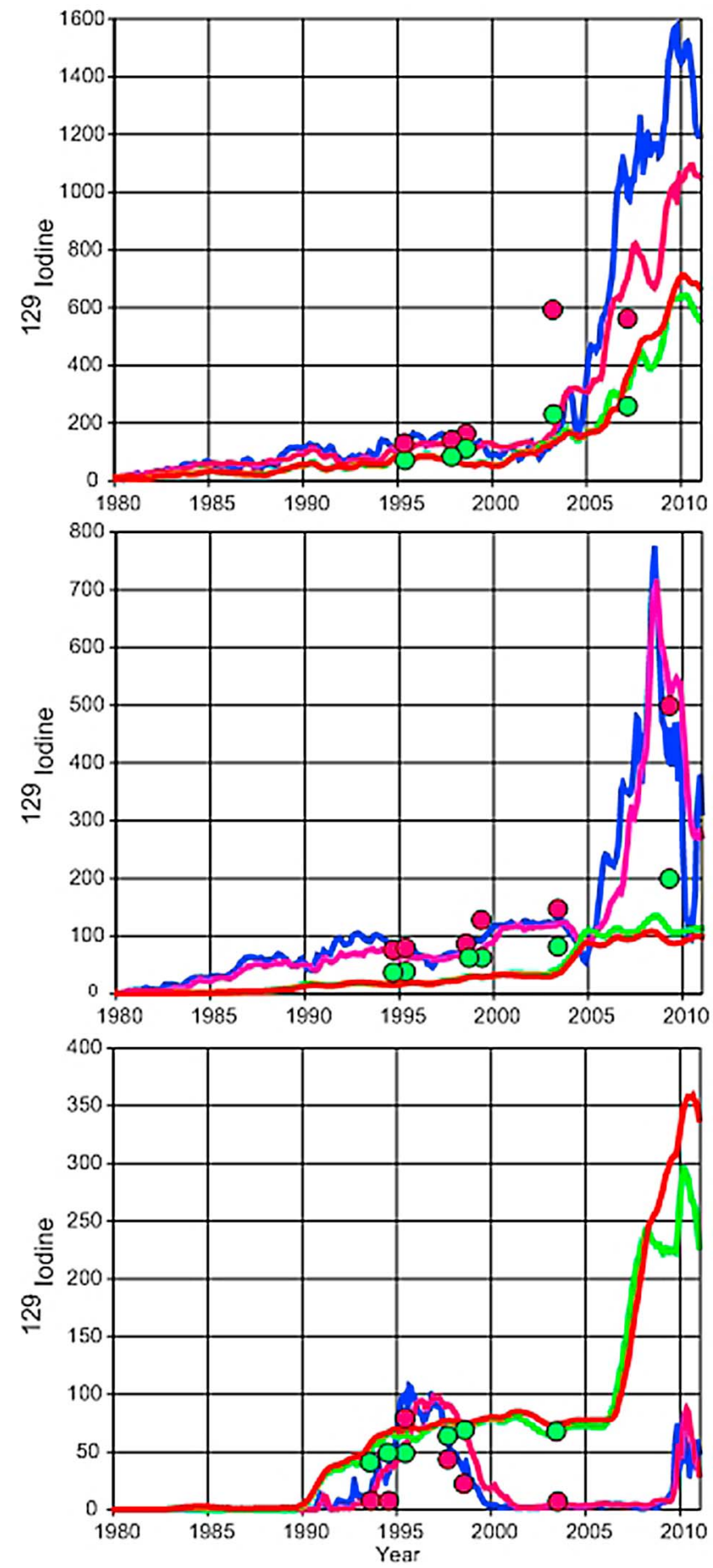

Figure 12. Curves represent monthly mean concentrations of simulated ${ }^{129} \mathrm{I}\left(10^{7}\right.$ at/l) at depth ranges: blue: 0-20 m; magenta: 60-80 m, green: 208-254 m; red: 312-385 m. Locations are (top) eastern Laptev Sea slope proximal to the Lomonosov Ridge (approx. $148.8^{\circ} \mathrm{E} ; 80.5^{\circ} \mathrm{N}$ ), (middle) North Pole (approx. $90^{\circ} \mathrm{N}$ ), and (bottom) Mendeleyev Ridge proximal to Chukchi Sea slope (approx. $80.5^{\circ} \mathrm{N} ; 180^{\circ} \mathrm{E}$ ). Actual ${ }^{129}$ I time series measurements are given by symbols for depths of 0-20 m (magenta) and 208-254 m (green). tracer distribution in the Canada Basin and velocity changes at the Alaskan slope, was associated with the strengthening of the Beaufort Gyre and a deepening of the surface mixed layer, together with an increase in its freshwater content [McPhee et al., 2009; Proshutinsky et al., 2009; Rabe et al., 2011]. These changes resulted from a period of increased Ekman-pumping due to a negative anomaly of the wind + ice stress curl in the entire Canadian Basin starting in 2004 (Figure 13, top) [see also Rabe et al., 2011]. For the same region Proshutinsky et al. [2009] found a doubling of negative wind stress curl for the 2000s as compared to earlier decades. Yang [2009] suggested that an increase in Ekman pumping in the Beaufort Sea for the period 1998 to 2004 (with peaks in 1998 and 2003/2004) was a consequence of varying ice velocities associated with changes in ice dynamics (thinner and less areal coverage). His analysis covers the period 1979-2006 in the center of Beaufort
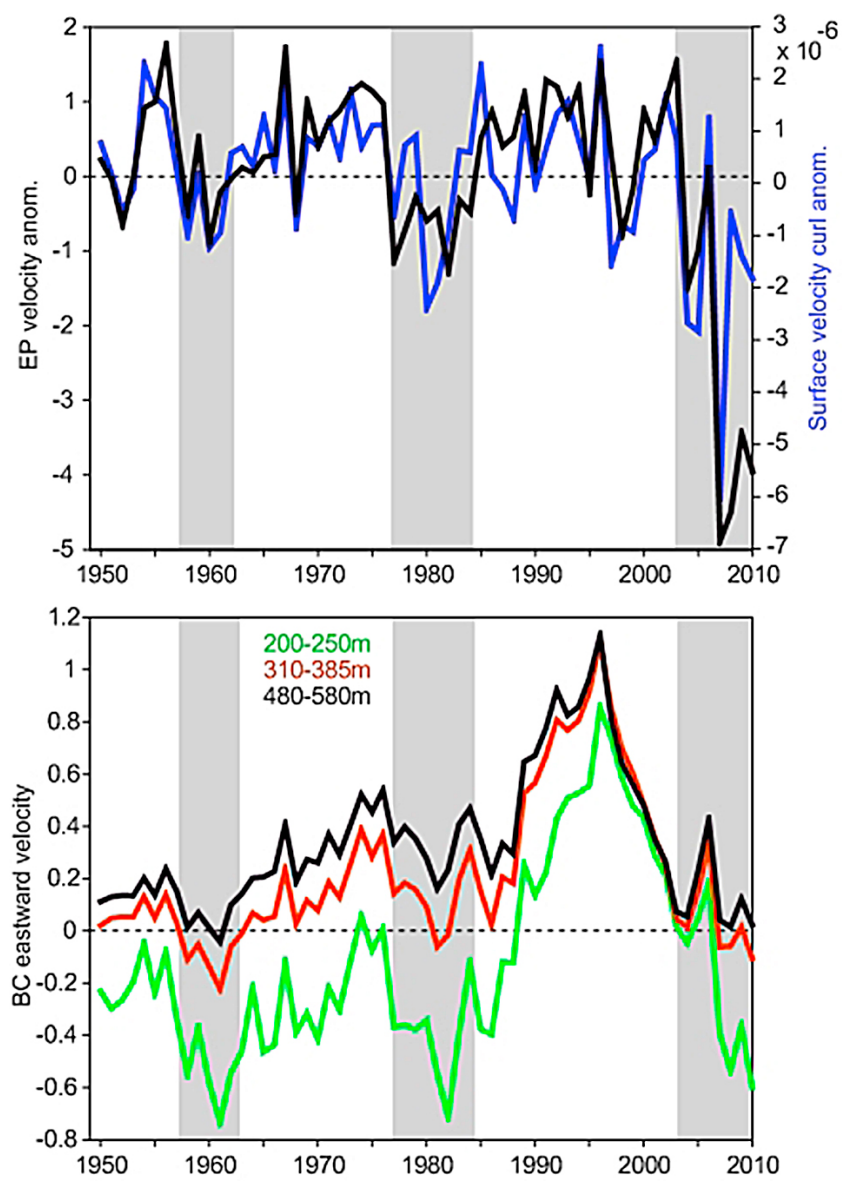

Figure 13. (top) Ekman Pumping ( $\mathrm{cm} / \mathrm{d}$, black curve) and curl of the surface currents $(1 / \mathrm{s}$, blue curve) in the Beaufort Gyre area $\left(130^{\circ}\right.$ to $170^{\circ} \mathrm{W}, 70.5^{\circ}$ to $80.5^{\circ} \mathrm{N}$, for water depths $>500 \mathrm{~m})$. The latter serves as a measure of the Gyre's intensity at the surface. (bottom) Mean eastward velocity $(\mathrm{cm} / \mathrm{s}$ ) at the Alaskan slope of the Beaufort Sea at water depths of 200-250 m (green curve), 310-385 m (red curve) and 480-580 m (black curve). All data are yearly means. The gray shaded years show periods of strong Ekman Pumping, which coincide with reduced eastward flow on the Alaskan slope. 
Sea. Karcher et al. [2007] showed that anti-cyclonic flow of AW could occur in the Canadian and Makarov basin as a result of an artificially intense, anti-cyclonic Beaufort Gyre forced over a period of several decades.

[27] The present work indicates that anti-cyclonic flow is possible for upper AW in a realistically forced setting. The shallower parts of the AW boundary current at the Alaskan slope seem to be more subject to anticyclonic flow reversal than the deeper layers. The results also show that previous periods of intensified Ekman pumping around 1960 and 1980 coincided with an intense Beaufort Gyre circulation and the reduction or even reversal in the AW boundary current at the Alaskan slope at all intermediate depth levels (Figure 13, gray shading). It should be noted that in the model simulation the direction of flow at the Alaskan slope is not necessarily representative of the circulation in the entire Canada Basin. Instead, it may be part of a smaller anticyclonic recirculation cell in the Beaufort Sea while the overall AW circulation in the Amerasian Basin may continue to be cyclonic, but with a shortened diversion extending from the Chukchi Plateau to the Canadian slope. Such situations occur in the model simulation in the 1950s to the 1970s (not shown). Early work from Newton and Coachman [1974], based on Coachman and Barnes [1963], found indications for such anticyclonic motion of AW in the Beaufort Sea, and a shortcut of AWL flow as described above. Their work is based on sparse data mostly from the 1960s, and deduces the flow direction based on the retention of AW characteristics, while disregarding temporal variability in the hydrography.

[28] The different hypothesized circulation regimes for the $1980 \mathrm{~s}, 1990 \mathrm{~s}$ and the late $2000 \mathrm{~s}$ are illustrated schematically in Figure 14 for surface water (Figures 14a, 14b, and 14c) and AWL depths (250-350 m depth; Figures 14d, 14e, and 14f). An anti-cyclonic regime prevailed at the surface in the 1980s (Figure 14a), which nevertheless allowed cyclonic flow at AWL depths (Figure 14d). It developed into a weaker anticyclonic surface circulation with a smaller Beaufort Gyre and a TPD relocated toward North America in the 1990s (Figure 14b). At AWL depths, during the 1990s intense cyclonic flow occurred in the Canadian and Makarov Basins, supported by strong AW flow across the Lomonosov Ridge (indicated by doubled arrows in Figure 14e). After 2004, the intense anti-cyclonic circulation of an enlarged Beaufort Gyre dominated in surface waters (Figure 14c). There was also a variable westward flow of water with an elevated fraction of Atlantic origin water separating from the Transpolar Drift north of Greenland and an accompanying redirection of the flow of Pacific-origin water from the western part of Fram Strait into the Canadian Archipelago (Figure 14c). The cyclonic flow of the underlying AWL also underwent a strong reduction in intensity after 2004 with the weakened flow along the Lomonosov Ridge indicated by a dashed line in Figure 14f. At the upper AW level a switch to large scale anti-cyclonic flow in the Canada Basin may have occurred, resulting in the development of a third type of circulation regime by the late 2000s (Figure 14f). However, the resulting flow around the Chukchi Plateau is not entirely clear from the present state of knowledge; thus this entire regime in this area has been denoted by a question mark in Figure 14f. Undoubtedly the flow of water north of the Chukchi Plateau into the central Canadian Basin originally stems from the boundary current, but it is unclear whether it has separated from the return flow along the Alpha-Mendeleyev Ridge or it separated from the northern slope of the Chukchi Plateau (Figure 14f, black arrow). Following 2004, intermediate waters in the Canada and Eurasian Basins appear to have lost their direct connection via the boundary currents formerly flowing eastward through the Makarov Basin over the Siberian continental slope. Instead, flow in the Makarov Basin has become more directly linked with the cyclonic circulation regime of the Eurasian Basin. Such a switch of regimes of the Makarov Basin has previously only been known to occur at the surface.

[29] These results are consistent with observations of McLaughlin et al. [2009] of a strong, mid-depth transport of AW along the continental slope south of the Chukchi Plateau in the late 1990s combined with the diminished propagation of anomalously warm, Atlantic boundary current water on the Alaskan slope by 2005-7. Our results are also consistent with the observations of diminished anti-cyclonic residual transport of AW along the slope in the Beaufort Sea in the early 2000s [Nikolopoulos et al., 2009]. McLaughlin et al. [2009] also speculate about anti-cyclonic, interior circulation in the Canadian basin, as inferred from dynamic height results at $400 \mathrm{~m}$ (ref. to $1000 \mathrm{~m}$ ) based on 2003-2007 data. The presence of weak, anti-cyclonic flow in the interior of the Canada Basin, including an eastward off-slope transport of AW from the northern tip of the Chukchi Plateau and a general southward flow tendency in the eastern Canada Basin provides additional support for the present model results. One further feature of the simulation that can be tested is an intermittent surface flow in the late 2000s (indicated by dashed lines in Figure 14c) which carries Atlantic-origin water westward along the northern slope of Greenland toward the Canada Basin leading to an intermittent blockage of the southward flow of Pacific-origin water toward Fram Strait. These model results are supported by observations of elevated ${ }^{129}$ I levels $\left(>200 \times 10^{7}\right.$ at $\left./ 1\right)$ in water collected north of Greenland in 2009 (Figure 8a) that clearly label this water mass as being mainly of Atlantic origin. Support for this westward flow is also provided by geostrophic velocities at depths of 50-60 m (relative to $500 \mathrm{dbar}$ ) for 2008 [Morison et al., 2012].

\section{Conclusions}

[30] Discharge records for the release of tracer ${ }^{129} \mathrm{I}$ from nuclear fuel reprocessing plants at Sellafield (UK) and La Hague (France) have been used as input functions for NAOSIM, a regional coupled sea ice-ocean model, to outline the circulation of Atlantic-origin water in the Arctic Ocean over the last few decades.

[31] The extensive spatial coverage of the ${ }^{129}$ I distribution in the Arctic Ocean during the mid-1990s [Smith et al., 1999] facilitates validation of the model results. The observed large changes in the upper ocean water mass distributions that were associated with the high AO index from 1989-1995 and the return to neutral values in the second half of the 1990s [Steele and Boyd, 1998; Morison et al., 2006] are reflected in the results of the ${ }^{129} \mathrm{I}$ simulation. It illustrates the observed intrusion of Atlantic-origin water into the Makarov and Canadian basins during the high AO phase of the 1990s, along with the movement of the surface front between 

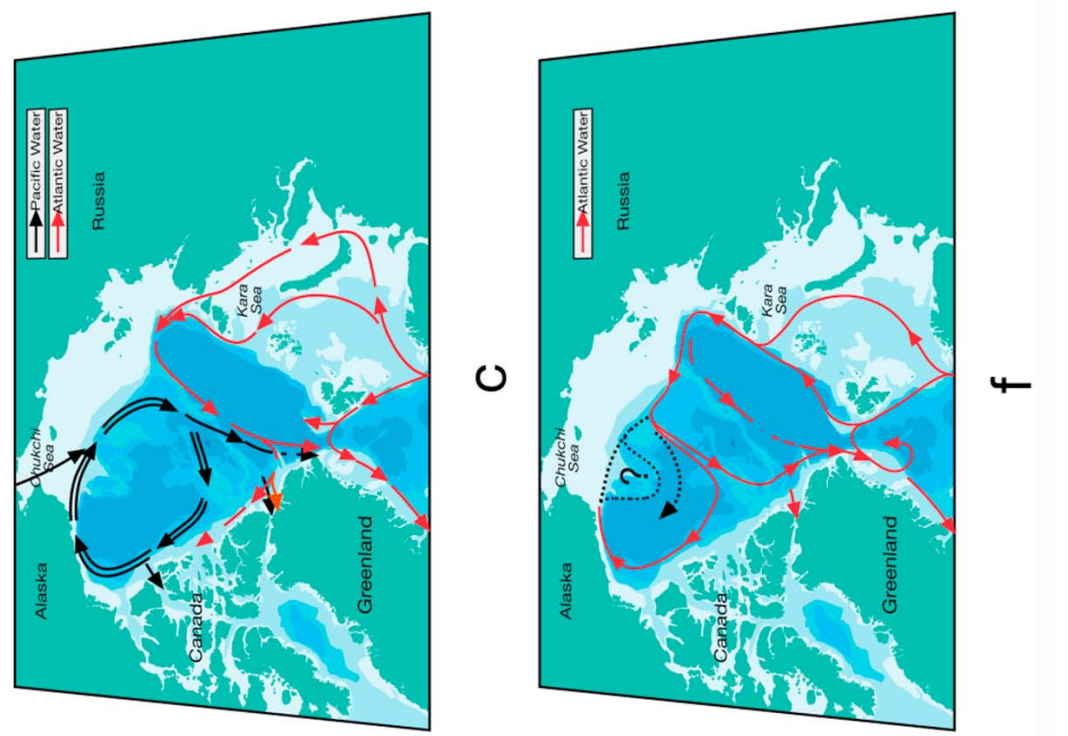

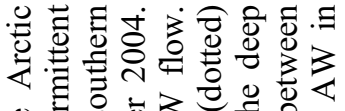
可

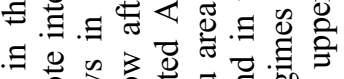

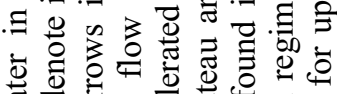

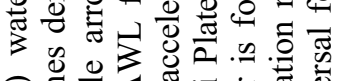

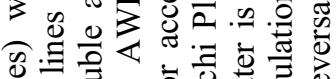

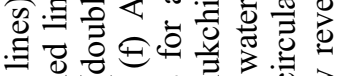

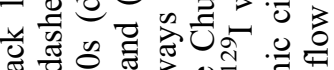

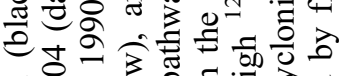
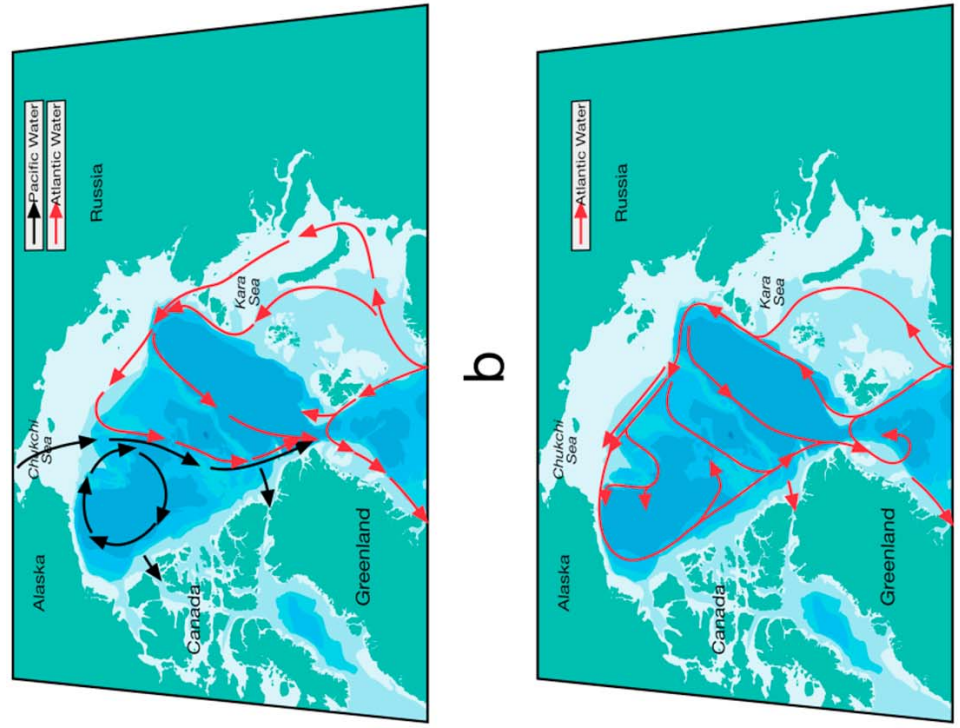

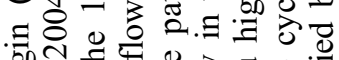

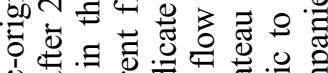

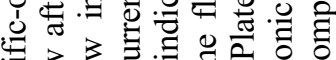

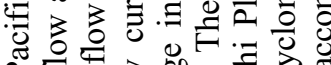

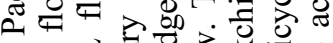

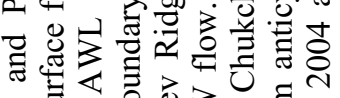

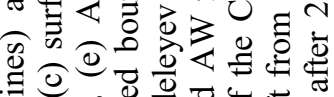

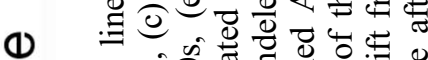

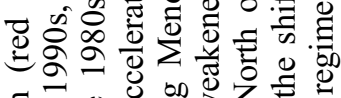
‡.च

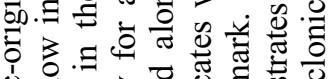

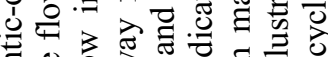

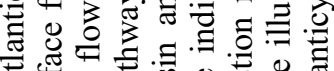

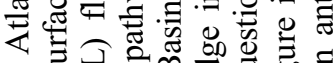

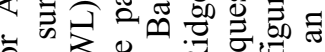

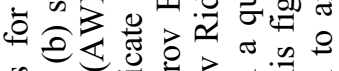
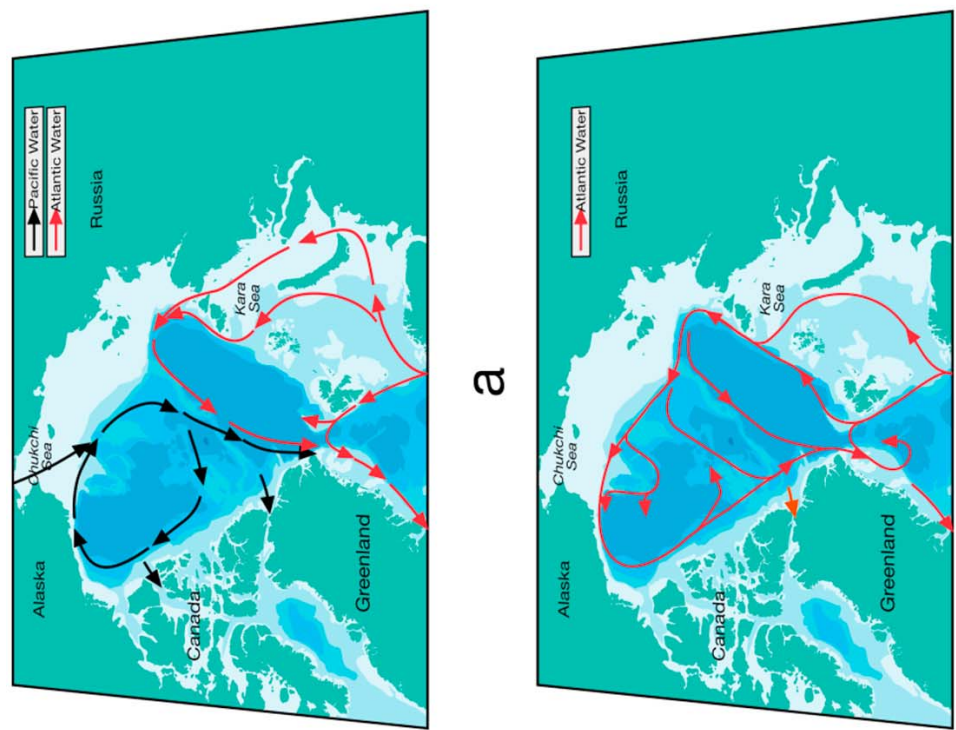

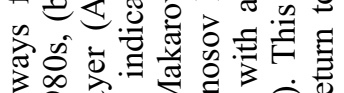

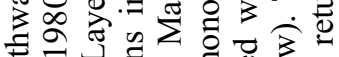
善

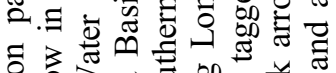

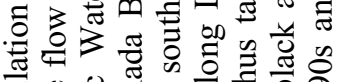

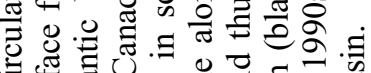

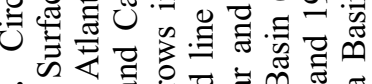

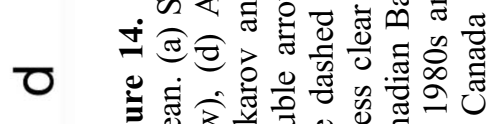

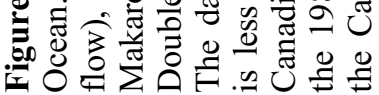


Atlantic- and Pacific-origin water from a position over the Lomonosov Ridge to one over the Mendeleyev Ridge.

[32] During the late 2000s, a period of exceptionally strong Ekman pumping in the Canadian basin and a very strong Beaufort Gyre with a high freshwater content resulted in the partial return of the surface circulation regime to that which prevailed prior to the 1990s. Low- ${ }^{129}$ I, Pacific-origin water constituted the principle component of the Polar Mixed Layer in the Canadian Basin during this period while high- ${ }^{129}$ I, Atlantic-derived water occupied the surface layer of the Eurasian Basin. The situation was more complicated at halocline and AW layer depths: ${ }^{129}$ I concentrations in the AW boundary current in the Canada Basin were lower than those in boundary currents in the Eurasian and Makarov Basin, in contrast to conditions that prevailed previously. This was the tracer expression of a dramatic change in Atlantic boundary current flow at intermediate depths. It consisted of a much reduced eastward progression of the boundary current along the continental slope, combined with its strong recirculation toward Fram Strait along the Mendeleyev and Alpha Ridges. Some intrusion of ${ }^{129} \mathrm{I}$ into the interior of the Canada Basin is also apparent in both observations and model results.

[33] The model simulation suggests a cause for the abrupt changes in AW circulation. Following 2004 the strong Ekman pumping in the Canadian Basin contributed to the development of an intense anti-cyclonic Beaufort Gyre, which tended to suppress the cyclonic AW flow. As a consequence, a reduction or even reversal of upper AW flow occurred in the Canada Basin. Support for this model simulation is provided by hydrographic observations indicating strong flow separation of AW from the northern Chukchi Plateau into the interior of the Canada Basin, a sluggish eastward flow of the AW boundary current and an anticyclonic tendency in the interior of the Canada Basin [McLaughlin et al., 2009; Nikolopoulos et al., 2009]. We submit that the anti-cyclonic wind-forcing led to convergent mass transport in the interior of the Canada Basin. The resulting sea level rise tended to promote barotropic anticyclonic circulation. Because of this strong barotropic flow, the compensation depth at which the flow switched from anti-cyclonic to cyclonic was deepened to water depths well into the intermediate water range. Further investigations are required to fully understand the coupling between the Beaufort Gyre and AW flow in the Canada Basin and its impact on AW flow paths. However, the potential for AW flow reversal is important, because this could lead to a decoupling of the flow regimes in the Canada and the Eurasian Basins at mid-depths and a significant decrease in the magnitude of water mass exchange between the basins. As a consequence an alteration of the source water characteristics of the Arctic intermediate depth water that supplies the overflows in the Nordic seas can be expected [Tanhua et al., 2008; Karcher et al., 2011].

[34] Acknowledgments. The authors would like to express their gratitude to the funding agencies of this research, namely the European Commission as part of the project ArcRisk 'Arctic Health Risks: Impacts on health in the Arctic and Europe owing to climate-induced changes in contaminant cycling' (FP7 GA226534), Fisheries and Oceans Canada under grant F5244-100131, the German Federal Ministry of Education and Research as part of the project 'Beiträge des Nordpolarmeers zu Veränderungen des Nordatlantiks' (03F0443D), and the U.S. National Science Foundation for grants OPP 02-30238 and ARC 06-33878. We also thank the AOMIP project (National Science Foundation Office of Polar Programs, award ARC-0804010) for our travel support to attend an AOMIP meeting and for financial support of this paper publication.

\section{References}

Alkire, M. B., K. K. Falkner, I. Rigor, M. Steele, and J. Morison (2007), The return of Pacific Waters to the upper layers of the central Arctic Ocean, Deep Sea Res., Part I, 54(9), 1509-1529, doi:10.1016/j.dsr. 2007.06.004.

Björk, G., J. Söderkvist, P. Winsor, A. Nikolopoulos, and M. Steele (2002), Return of the cold halocline layer to the Amundsen Basin of the Arctic Ocean: Implications for the sea ice mass balance, Geophys. Res. Lett., 29(11), 1513, doi:10.1029/2001GL014157.

Carmack, E. C., R. W. Macdonald, R. G. Perkin, F. A. McLaughlin, and R. J. Pearson (1995), Evidence for warming of Atlantic water in the southern Canadian Basin of the Arctic Ocean: Results from the Larsen-93 expedition, Geophys. Res. Lett., 22, 1061-1064, doi:10.1029/95GL00808.

Carmack, E. C., K. Aagaard, J. H. Swift, R. W. Macdonald, F. A. McLaughlin, E. P. Jones, R. G. Perkin, J. N. Smith, K. M. Ellis, and L. R. Killlius (1997), Changes in temperature and tracer distributions within the Arctic Ocean: Results from the 1994 Arctic Ocean section, Deep Sea Res., Part II, 44, 1487-1502, doi:10.1016/S0967-0645(97) 00056-8.

Coachman, L. K., and C. A. Barnes (1963), The movement of Atlantic Water in the Arctic Ocean, Arctic, 16(1), 8-16.

Edmonds, H. N., J. N. Smith, L. R. Kilius, H. D. Livingston, and J. M. Edmond (1998), ${ }^{129}$ I in archived seawater samples, Deep Sea Res., Part I, 45, 1111-1125, doi:10.1016/S0967-0637(98)00007-7.

Falck, E., G. Kattner, and G. Budeus (2005), Disappearance of Pacific Water in the northwestern Fram Strait, Geophys. Res. Lett., 32, L14619, doi:10.1029/2005GL023400.

Gascard, J. C., G. Raisbeck, S. Sequeira, F. Yiou, and K. A. Mork (2004), The Norwegian Atlantic Current in the Lofoten Basin inferred from hydrological and tracer data $\left({ }^{129} \mathrm{I}\right)$ and its interaction with the Norwegian Coastal Current, Geophys. Res. Lett., 31, L01308, doi:10.1029/ 2003GL018303.

Gerdes, R., M. Karcher, F. Kauker, and C. Koeberle (2001), Predicting the spread of radioactive substances from Kursk, Eos Trans. AGU, 82(23), 253.

Gerdes, R., M. Karcher, F. Kauker, and U. Schauer (2003), Causes and development of repeated Arctic Ocean warming events, Geophys. Res. Lett., 30(19), 1980, doi:10.1029/2003GL018080.

Hibler, W. D. (1979), A dynamic thermodynamic sea ice model, J. Phys. Oceanogr., 9, 815-846, doi:10.1175/1520-0485(1979)009<0815: ADTSIM $>2.0 . C O ; 2$

Holland, D. M., L. A. Mysak, and J. M. Oberhuber (1996), An investigation of the general circulation of the Arctic Ocean using an isopycnal model, Tellus, Ser. A, 48, 138-157, doi:10.1034/j.1600-0870.1996.00008.x.

Holloway, G., A. Nguyen, and Z. Wang (2007), Water properties and circulation in Arctic Ocean models, J. Geophys. Res., 112, C04S03, doi:10.1029/2006JC003642.

Josefsson, D. (1998), Anthropogenic radionuclides in the Arctic Ocean, $\mathrm{PhD}$ thesis, Lund University, Lund, Sweden.

Kalnay, E., et al. (1996), The NCEP/NCAR 40-Year Reanalysis Project, Bull. Am. Meteorol. Soc., 77(3), 437-471, doi:10.1175/1520-0477 (1996) $077<0437$ :TNYRP $>2.0$. CO;2

Karcher, M. J., and J. M. Oberhuber (2002), Pathways and modification of the upper and intermediate water of the Arctic Oceans, J. Geophys. Res., 107(C6), 3049, doi:10.1029/2000JC000530.

Karcher, M., R. Gerdes, F. Kauker, and C. Koeberle (2003), Arctic warming: Evolution and spreading of the 1990s warm event in the Nordic Seas and the Arctic Ocean, J. Geophys. Res., 108(C2), 3034, doi:10.1029/ 2001JC001265.

Karcher, M. J., S. Gerland, I. Harms, M. Iosipe, H. Heldal, P. J. Kershaw, and M. Sickel (2004) The dispersion of technetium-99 in the Nordic Seas and the Arctic Ocean: A comparison of model results and observations, J. Environ. Rad., 74(1-3), 185-198.

Karcher, M., R. Gerdes, and F. Kauker (2006), Modeling of delta ${ }^{18} \mathrm{O}$ and ${ }^{99}$ Tc dispersion in Arctic and subarctic seas, ASOF Newsl., 5, 19-20.

Karcher, M., F. Kauker, R. Gerdes, E. Hunke, and J. Zhang (2007), On the dynamics of Atlantic Water circulation in the Arctic Ocean, J. Geophys. Res., 112, C04S02, doi:10.1029/2006JC003630.

Karcher, M., A. Beszczynska-Möller, F. Kauker, R. Gerdes, S. Heyen, B. Rudels, and U. Schauer (2011), Arctic Ocean warming and its consequences for the Denmark Strait overflow, J. Geophys. Res., 116, C02037, doi:10.1029/2010JC006265.

Kauker, F., R. Gerdes, M. Karcher, C. Koeberle, and J. L. Lieser (2003), Variability of Arctic and North Atlantic sea ice: A combined analysis of 
model results and observations from 1978 to 2001, J. Geophys. Res., 108 (C6), 3182, doi:10.1029/2002JC001573.

Kershaw, P., and A. Baxter (1995), The transfer of reprocessing wastes from north-west Europe to the Arctic, Deep Sea Res., 42, 1413-1448, doi:10.1016/0967-0645(95)00048-8.

Kilius, L. R., J. C. Rucklidge, and C. Soto (1994), The dispersal of ${ }^{129} \mathrm{I}$ from the Columbia River estuary, Nucl. Instrum. Methods Phys. Res. Sect. B, 92, 393-397, doi:10.1016/0168-583X(94)96041-0.

Köberle, C., and R. Gerdes (2003), Mechanisms determining the variability of Arctic sea ice conditions and export, J. Clim., 16, 2843-2858, doi:10.1175/1520-0442(2003)016<2843:MDTVOA $>2.0$. CO;2.

McLaughlin, F. A., E. C. Carmack, W. J. Williams, S. Zimmermann, K. Shimada, and M. Itoh (2009), Joint effects of boundary currents and thermohaline intrusions on the warming of Atlantic water in the Canada Basin, 1993-2007, J. Geophys. Res., 114, C00A12, doi:10.1029/ 2008JC005001.

McPhee, M. G., A. Proshutinsky, J. H. Morison, M. Steele, and M. B. Alkire (2009), Rapid change in freshwater content of the Arctic Ocean, Geophys. Res. Lett., 36, L10602, doi:10.1029/2009GL037525.

Morison, J., M. Steele, T. Kikuchi, K. Falkner, and W. Smethie (2006), Relaxation of central Arctic Ocean hydrography to pre-1990s climatology, Geophys. Res. Lett., 33, L17604, doi:10.1029/2006GL026826.

Morison, J., R. Kwok, C. Peralta-Ferriz, M. Alkire, I. Rigor, R. Andersen, and M. Steele (2012), Changing Arctic Ocean freshwater pathways, Nature, 481, 66-70, doi:10.1038/nature10705.

Newton, J. L., and L. K. Coachman (1974), Atlantic Water Circulation in the Canada Basin, Arctic, 27(4), 297-303.

Nikolopoulos, A., R. S. Pickart, P. S. Fratantoni, K. Shimada, D. J. Torres, and E. P. Jones (2009), The western Arctic boundary current at $152^{\circ} \mathrm{W}$ : Structure, variability, and transport, Deep Sea Res., Part II, 56, 1164-1181, doi:10.1016/j.dsr2.2008.10.014.

Orre, S., J. Smith, V. Alfimov, and M. Bentsen (2009), Simulating transport of ${ }^{129}$ I and idealized tracers in the northern North Atlantic Ocean, Environ. Fluid Mech., 10, 213-233, doi:10.1007/s10652-009-9138-3.

Pacanowski, R. C. (1995), MOM 2 documentation, user's guide and reference manual, GFDL Ocean Group Tech. Rep. 3, Geophys. Fluid Dyn. Lab., Princeton Univ., Princeton, N. J.

Proshutinsky, A., and M. A. Johnson (1997), Two circulation regimes of the wind-driven Arctic Ocean, J. Geophys. Res., 102, 12,493-12,514, doi:10.1029/97JC00738

Proshutinsky, A., R. Krishfield, M.-L. Timmermans, J. Toole, E. Carmack, F. McLaughlin, W. J. Williams, S. Zimmermann, M. Itoh, and K. Shimada (2009), Beaufort Gyre freshwater reservoir: State and variability from observation, J. Geophys. Res., 114, C00A10, doi:10.1029/2008JC005104 [Printed 115(C1), 2010.]

Rabe, B., M. Karcher, U. Schauer, J. M. Toole, R. A. Krishfield, S. Pisarev, F. Kauker, R. Gerdes, and T. Kikuchi (2011), An assessment of Arctic Ocean freshwater content changes from the 1990s to the 2006-2008 period, Deep Sea Res., Part I, 58, 173-185, doi:10.1016/j.dsr.2010.12.002.

Raisbeck, G. M., and F. Yiou (2002), Use of ${ }^{129}$ I as an oceanographic tracer in the Nordic Seas, paper presented at 5th International Conference on Environmental Radioactivity in the Arctic and Antarctic, Norw. Radiat. Protect. Authority, St. Petersburg, Russia, 16-20 June.

Rudels, B., E. P. Jones, L. G. Anderson, and G. Kattner (1994), On the intermediate depth waters of the Arctic Ocean, in The Role of the Polar Oceans in Shaping the Global Climate, Geophys. Monogr. Ser., vol. 85, edited by O. M. Johanessen, R. D. Muench, and J. E. Overland, pp. 33-46, AGU, Washington, D. C., doi:10.1029/GM085p0033.
Rudels, B., H. J. Friedrich, and D. Quadfasel (1999), The Arctic Circumpolar Boundary Current, Deep Sea Res., Part II, 46(6-7), 1023-1062, doi:10.1016/S0967-0645(99)00015-6.

Rudels, B., E. P. Jones, U. Schauer, and P. Eriksson (2004), Atlantic sources of the Arctic Ocean surface and halocline waters, Polar Res., 23, 181-208, doi:10.1111/j.1751-8369.2004.tb00007.x.

Schlosser, P., J. H. Swift, D. Lewis, and S. L. Pfirman (1995), The role of the large-scale Arctic Ocean circulation in the transport of contaminants, Deep Sea Res., Part II, 42, 1341-1367, doi:10.1016/0967-0645 (95)00045-3.

Smethie, W. M., Jr., P. Schlosser, G. Bönisch, and T. S. Hopkins (2000), Renewal and circulation of intermediate waters in the Canadian Basin observed on the SCICEX 96 cruise, J. Geophys. Res., 105, 1105-1121, doi:10.1029/1999JC900233.

Smethie, W. M., Jr., D. Chayes, R. Perry, and P. Schlosser (2011), A lightweight vertical rosette for deployment in ice-covered waters, Deep Sea Res., Part I, 58, 460-467, doi:10.1016/j.dsr.2010.12.007.

Smith, J. N., K. M. Ellis, and L. R. Kilius (1998), ${ }^{129}$ I and ${ }^{137}$ Cs tracer measurements in the Arctic Ocean, Deep Sea Res., 45, 959-984, doi:10.1016/ S0967-0637(97)00107-6.

Smith, J. N., K. M. Ellis, and T. M. Boyd (1999), Circulation features in the central Arctic Ocean revealed by nuclear fuel reprocessing tracers from SCICEX 95 and 96, J. Geophys. Res., 104, 29,663-29,677, doi:10.1029/1999JC900244.

Smith, J. N., F. A. McLaughlin, W. M. Smethie Jr., S. B. Moran, and K. Lepore (2011), Iodine-129, 137Cs, and CFC-11 tracer transit time distributions in the Arctic Ocean, J. Geophys. Res., 116, C04024, doi:10.1029/2010JC006471.

Steele, M., and T. Boyd (1998), Retreat of the cold halocline layer in the Arctic Ocean, J. Geophys. Res., 103(C5), 10,419-10,435, doi:10.1029/ 98JC00580

Steele, M., R. Morley, and W. Ermold (2001), PHC: A global ocean hydrography with a high quality Arctic Ocean, J. Clim., 14, 2079-2087, doi:10.1175/1520-0442(2001)014<2079:PAGOHW>2.0.CO;2.

Steele, M., J. Morison, W. Ermold, I. Rigor, M. Ortmeyer, and K. Shimada (2004), Circulation of summer Pacific halocline water in the Arctic Ocean, J. Geophys. Res., 109, C02027, doi:10.1029/2003JC002009.

Stevens, D. P. (1991), The open boundary condition in the United Kingdom Fine-Resolution Antarctic Model, J. Phys. Oceanogr., 21, 1494-1499, doi:10.1175/1520-0485(1991)021<1494:TOBCIT>2.0.CO;2.

Swift, J. H., E. P. Jones, E. C. Carmack, M. Hingston, R. W. Macdonald, F. A. McLaughlin, and R. G. Perkin (1997), Waters of the Makarov and Canada Basins, Deep Sea Res., Part II, 44, 1503-1529, doi:10.1016/ S0967-0645(97)00055-6.

Tanhua, T., K. A. Olsson, and E. Jeansson (2008), Tracer evidence of the origin and variability of Denmark Strait Overflow Water, in ArcticSubarctic Ocean Fluxes: Defining the Role of the Nordic Seas in Climate, edited by R. R. Dickson, J. Meincke, and P. Rhines, pp. 475-503, Springer, New York.

Tanhua, T., E. P. Jones, E. Jeansson, S. Jutterström, W. M. Smethie Jr., D. W. R. Wallace, and L. G. Anderson (2009), Ventilation of the Arctic Ocean: Mean ages and inventories of anthropogenic $\mathrm{CO}_{2}$ and $\mathrm{CFC}-11$, J. Geophys. Res., 114, C01002, doi:10.1029/2008JC004868.

Yang, J. (2009), Seasonal and interannual variability of downwelling in the Beaufort Sea, J. Geophys. Res., 114, C00A14, doi:10.1029/ 2008JC005084. 